\title{
An Overview of Genus Aesculus L.: Ethnobotany, Phytochemistry, and Pharmacological Activities
}

\author{
Zhizhen Zhang ${ }^{1, *}$, Shiyou $\mathrm{Li}^{2}$ and Xiao-Yuan Lian ${ }^{3}$ \\ ${ }^{I}$ NovoBiotic Pharmaceuticals, Cambridge, Massachusetts, 02138, USA \\ ${ }^{2}$ National Center for Pharmaceutical Crops, Arthur Temple College of Forestry and Agriculture, Stephen F. Austin State \\ University, Nacogdoches, Texas 75962-6109, USA \\ ${ }^{3}$ College of Pharmaceutical Sciences, Zhejiang University, Hangzhou 310058, P. R. China
}

\begin{abstract}
The genus Aesculus L. (Hippocastanaceae) has 12 species distributed in eastern Asia, eastern and western North America, and Europe. In Europe and the United States, A. hippocastanum has been used for the treatment of chronic venous insufficiency, hemorrhoids, and postoperative edema. In China, A. chinensis var. chinense has been used as a stomachic and analgesic in the treatment of distention and pain in the chest and the abdomen, malaria, dysentery, and heart disease. The objective of this paper is to review the ethnobotany, phytochemistry, and pharmacological properties of the genus Aesculus. To date, more than 210 compounds have been isolated and identified primarily from the fruits or seeds of Aesculus, with polyhydroxylated triterpenoid saponins as the major active principles. Studies have confirmed that Aesculus seed extracts and isolates possess diverse activities, including anti-inflammatory, antitumor, antiviral, antifungal, antiangiogenic (vascular protection), anti-obesity, antioxidative, and antigenotoxic properties. Interestingly, detailed studies of the saponins from more eastern North American species and other uninvestigated Aesculus species are necessary to further confirm the chemotaxonomic value of the novel cytotoxic saponins discovered recently from A. pavia, an eastern North American species, and to fully understand the chemical profile of the genus. Animal investigations of these novel cytotoxic saponins on the potential for the treatment of cancer are also intriguing.
\end{abstract}

Keywords: Aesculus; horse chestnut; buckeyes; ethnobotany; phytochemistry; triterpenoid saponins; bioactivities; anti-tumor activity.

\section{INTRODUCTION}

Aesculus L. is a genus of the family Hippocastanaceae containing 12 species of deciduous trees and shrubs in the northern hemisphere, primarily in eastern Asia and eastern North America, with one species native to Europe, and two to western North America [1-4]. Aesculus have been cultivated as pharmaceutical crops for the production of Standardized Therapeutic Extracts (STEs). There are two Eurasian species commonly used in medicine: A. hippocastanum (common horse chestnut) and $A$. chinensis var. chinensis (Chinese horse chestnut). In Europe, the bark, leaves, horse chestnut seed extract (HCSE), and aescin (a saponin mixture) from $A$. hippocastanum have been used in the treatment of chronic venous insufficiency, hemorrhoids, and postoperative edema [5-9]. In China, the seeds of $A$. chinensis var. chinensis have been used as a stomachic and analgesic in the treatment of distention and pain in chest and abdomen, malaria, and dysentery [10] and tablets made from the seeds are also used for treating heart diseases [11]. Modern pharmacologic investigations have confirmed that HCSE, aescin and individual compounds isolated and identified from the two Eurasian species and other Aesculus species possess diverse activities, including anti-inflammatory, antitumor, antiviral,

*Address correspondence to this author at the NovoBiotic Pharmaceuticals, Cambridge, Massachusetts, 02138, USA; Tel: 1-617-864-2880;

Fax: 1-617-864-2293; E-mail: zzhang@novobiotic.com antioxidative, and antigenotoxic properties. The chemical constituents of some Aesculus species have been well documented. To date, more than 210 compounds from different classes have been isolated and identified from the genus Aesculus. These compounds include triterpenoids, triterpenoid glycosides (saponins), flavonoids, coumarins, carotenoids, long fatty chain compounds, and some other classes of compounds. The present paper with 108 references reviews the research advances in the enthnobotany, phytochemistry and phamarcological activities of the genus Aesculus.

\section{BOTANY, CULTIVATION, AND MEDICAL USES}

To date, over a hundred species or varieties in Aesculus have been described because of great morphological variations due to natural pollination among the species. In his monograph of Aesculus, Koch (1857) recognized 13 species in four subgenera, Hippocastanum, Pavia, Calothyrsus, and Macrothyrsus [12]. Based on bud viscidity, fruit exocarp ornamentation, flower color, and petal morphology, the 13 species were grouped into five sections [1, 2, 13]. All new species discovered in the last several decades are not recognized and thus most authors recognized 13 species in the genus until $A$. wilsonii Rehder was recently treated as a variety under the species $A$. chinensis Bunge [3, 14]. The 12 currently recognized species in the genus Asculus are grouped in the five sections: Section Aesculus in Europe and Japan (A. hippocastanum L. and A. turbinata Blume), Sec- 
tion Calothyrsus (Spach) K. Koch in Southeastern Asia and western United States (A. assamica Griffith, A. californica (Spach) Nutall, A. chinensis Bunge var. chinensis, A. chinensis Bunge var. wilsonii ((Rehder) Turland \& N.H. Xia, and A. indica (Camb.) Hook.), Section Pavia (Mill.) Persoon in the southeastern United States (A. glabra Willd. var. glabra, A. glabra Willd. var. arguta (Buckl.) Robinson, A. flava Sol., A. pavia L., and A. sylvatica Bartram), Section Macrothyrsus (Spach) K. Koch in the southeastern United States (A. parviflora Walter), and Section Parryanae Wiggins in Baja California, Mexico (A. parryi A. Gray) (Table 1).

The recent phylogenetic analysis of Aesculus by DNA sequences of chloroplast gene $m a t K$ and internal transcribed spacers of nuclear ribosomal RNA genes supported Hardin's classification except for section Calothyrsus [4]. Some chemotaxonomical analysis has been conducted [15]. Interestingly, A. pavia in the Section Pavia has tritepernoid saponins with an oligosaccharide chain at $\mathrm{C}-3$ of the aglycone with an $\alpha$-arabinofuranosyl unit affixed to $\mathrm{C}-3$ of the glucuronic acid while Eurasian species in Section Aesculus and Section $\mathrm{Ca}$ lothyrsus have saponins with a trisaccharide chain at C-3 of the aglycone with a $\beta$-glucopyranosyl unit attached to C-4 of the glucuronic acid [16] (see Triterpenoid Saponins for details). This significant chemical difference suggests that triterpenoid saponins may provide important clues in understanding the systematics and evolution of the genus Aesculus.

Aesculus are deciduous trees or shrubs with easily recognizable palmately compound leaves (5-11 leaflets), characteristic capsules and seeds, and attractive ornamental flowers. Aesculus hippocastanum has been cultivated since 1576 as an ornamental plant [17] while A. chinensis var. chinensis has been planted in temples and homes for several centuries. At present, all species are cultivated, with at least 27 commercial cultivars supplied by at least 95 nurseries in the United States [17]. Most species are propagated from seeds and the cultivars by budding or grafting. In Europe, HCSE and aescin are major pharmaceutical products from Aesculus.

Aesculus hippocastanum is a large deciduous tree, also known as Conker tree. This species is native to a small area in the mountains of the Balkans in southeast Europe, in small areas in northern Greece, Albania, the Republic of Macedonia, Serbia, and Bulgaria. It is now widely cultivated throughout the temperate world because of its large, beautiful flower clusters and its excellent resistance to environmental conditions. The leaves of this species are opposite and palmately compound with 5-7 leaflets. The sessile leaflets are green beneath with obtusely double-serrate. Its flowers are usually white with a small red spot. The fruit is a green, spiky capsule containing one (rarely two or three) brown seed, called chestnut or conker [2].

The common name "horse chestnut" may have come from the uses of seeds for horses to treat overexertion or coughs by Turks and Greeks [18]. Dated from the early 18th century, the horse chestnut has a therapeutic property for anti-fever [5]. In Europe, the bark and leaves of A. hippocastanum have been employed as an astringent to treat diarrhea and hemorrhoids [6]. The HCSE from A. hippocastanum has been used in the treatment of chronic venous insufficiency, hemorrhoids, and postoperative edema [7-9]. Aescin, also known as $\beta$-escin, is the major active component in HCSE and has been shown to have a clinically significant activity in chronic venous insufficiency, hemorrhoids, and postoperative edema. The pharmacology, pharmacokinetics and therapeutic profile of aescin have been reviewed [5]. Based on the publication over the last two decades of numerous randomized controlled trials in prominent, peer-reviewed journals, A. hippocastanum extract is gaining wider acceptance as an effective therapy for venous disorders and edema in the United States [5].

Aesculus chinensis is native to China and is distributed mainly in the Hebei, Henan, and Shanxi provinces. The fruits of this species usually are smooth subglobose, truncate to slightly impressed at the apex, thickly walled with smaller seeds having proportionately larger hilum. The surface of its petiolulate leaflets is glabrous or sparingly pilose [2]. Its seeds, called "Sha Luo Zhi" in traditional Chinese medicine, have long been used as a stomachic and analgesic in the treatment of distention and pain in chest and abdomen, malaria, and dysentery [10]. Additionally, the tablets made from the seeds are used for treating heart diseases [11].

Aesculus turbinata, known as Japanese horse chestnut, is native only to Japan. It has been found on the island of Hokkaido and the central and northern parts of Honshu. This species has been widely cultured in England, the United States, and China. This species is similar to A. hippocastanum, differently mainly in the slightly smaller flowers, warty fruit surface, and in the larger leaves, which are glaucescent beneath and have more regularly crenate-serrate margins [2]. The seeds of the Japanese horse chestnut have been used as an emergency provision since ancient times and utilized traditionally in Japan as a confectionery ingredient in rice cakes and rice balls [19]. Its seed extract in combination with spirits have also been used as a folk medicine for the treatment of bruises and sprains in some regions of Japan [20].

Aesculus indica, known as Indian horse chestnut, is found on mountain slopes or in moist and shady valleys in the northwestern Himalayan forests. It is distributed from Nepal northwestward into the State of Kashmir in north India, and across the Indus River to West Pakistan and to northeastern Afghanistan. Its fruits are reddish brown, smooth ovoids. The petiolulate leaflets of this species are submembranacous with finely serrate margin [2]. In some parts of Himachal Pradesh, the seeds are dried and grounded into flour, called tattwakhar. This flour is bitter and used for making halwa, which is taken as phalahar (non-cereal food) during fasts; the leaves are used as a fodder for cattle. India horse chestnut also has medicinal properties for animals and human beings. The fruits are given to horses suffering from colic. The oil extracted from the seeds is used to cure rheumatism [21].

Seeds of North American species (e.g., A. pavia, A. flava, A. glabra, and A. californica), known as buckeyes, were used by Native Americans to tranquilize fish to make them easier to catch [22]. Extracts from the seeds were used to treat earaches, sores, colic, sprains, and chest pains [23]. Powdered bark was sometimes used to alleviate toothaches and ulcer pain [24]. 
Table 1. Species List of Aesculus L

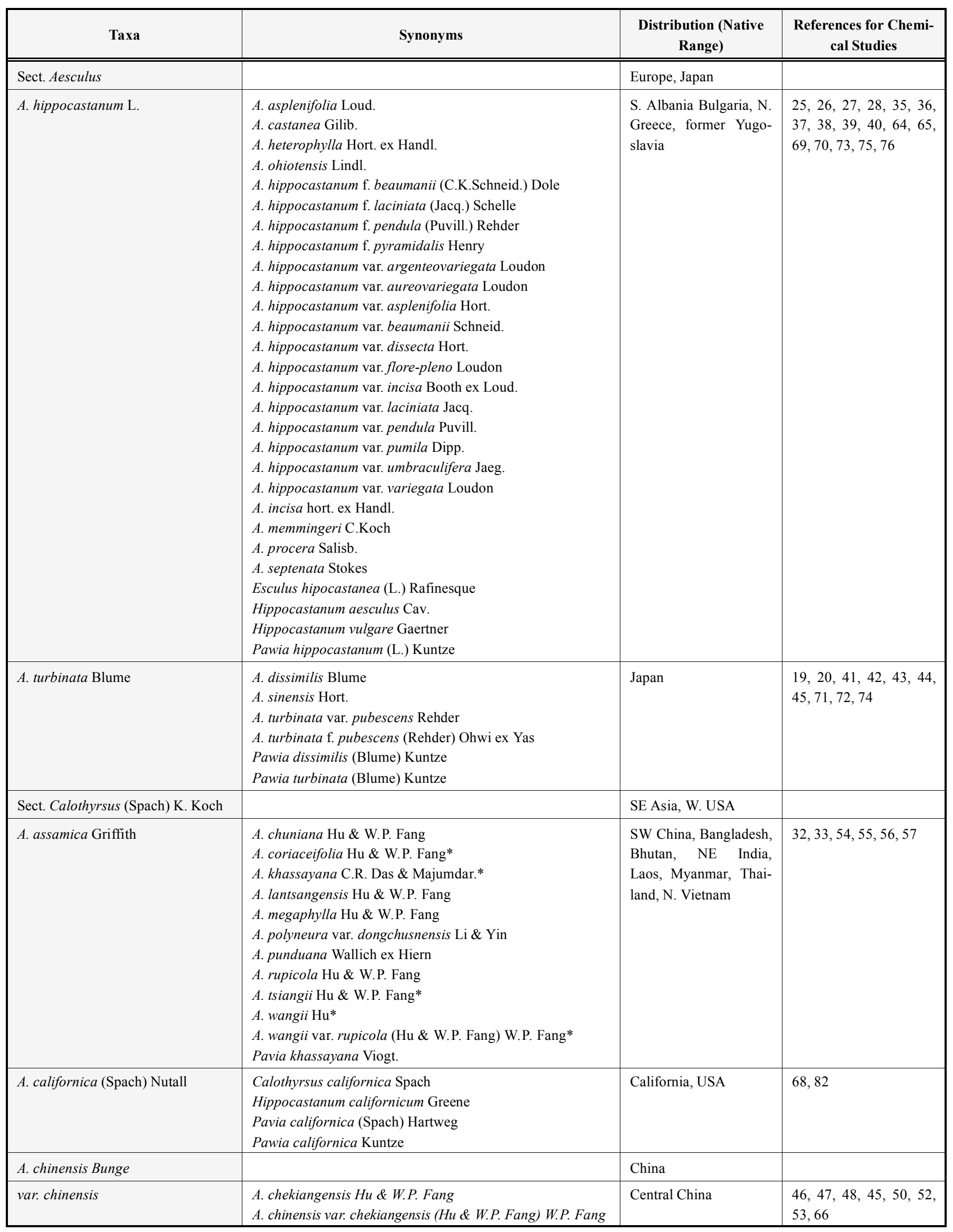


Table 1. contd....

\begin{tabular}{|c|c|c|c|}
\hline Taxa & Synonyms & $\begin{array}{c}\text { Distribution (Native } \\
\text { Range) }\end{array}$ & $\begin{array}{c}\text { References for Chemi- } \\
\text { cal Studies }\end{array}$ \\
\hline $\begin{array}{l}\text { var. wilsonii (Rehder) } \\
\text { Turland \& N.H. Xia }\end{array}$ & $\begin{array}{l}\text { A. wilsonii Rehder } \\
\text { Actinotinus sinensis Oliver }\end{array}$ & Central and SW China & $32,33,34,79,83$ \\
\hline A. indica (Camb.) Hook. & $\begin{array}{l}\text { A. indica var. concolor Browicz } \\
\text { Pavia indica Wall. ex Cambess }\end{array}$ & Himalayas & $\begin{array}{l}29,58,59,60,62,63, \\
76,77,78\end{array}$ \\
\hline Sect. Pavia (Mill.) Persoon & & SE USA & \\
\hline \multicolumn{4}{|l|}{ A. glabra Willd. } \\
\hline var. glabra & $\begin{array}{l}\text { A. ohioensis De Candolle } \\
\text { Nebropsis glabra (Willd.) Rafinesque } \\
\text { Pavia glabra (Willd.) Spach } \\
\text { Pawia glabra (Willd.) Kuntze }\end{array}$ & & 31 \\
\hline var. arguta (Buckl). Robinson & A. arguta Buckl. & & \\
\hline A. flava Sol. & $\begin{array}{l}\text { A. flava Aiton } \\
\text { A. flava f. vestita (Sargent) Fernald } \\
\text { A. flava var. virginica (Sargent) Fernald } \\
\text { A. flava var. purpurascens A. Gray } \\
\text { A. flava var. purpurea Hort } \\
\text { A. flava var. rosea Hort } \\
\text { A. flava var. sanguinea Hort } \\
\text { A. lutea Wangh. } \\
\text { A. maxima D. Drake } \\
\text { A. octandra Mrshall } \\
\text { A. octandra f. vestita (Sargent) Fernald } \\
\text { A. octandra f. virginica (Sargent) Fernald } \\
\text { A. octandra var. purpurascens (A.Gray) C.K.Schneid } \\
\text { A. octandra var. vestita Sargent } \\
\text { A. octandra var. virginica Sargent } \\
\text { Pavia bicolor Rafinesque } \\
\text { P. flava (Sol.) Moench } \\
\text { P. fulva Rafinesque } \\
\text { P. lutea Poir. } \\
\text { Pavia reticulata Rafinesque } \\
\text { Paviana flava (Sol.) Rafinesque } \\
\text { Pawia octandra (Marshall) Kuntze } \\
\text { P. octandra var. flava (Sol.) Kuntze }\end{array}$ & & \\
\hline A. pavia $L$. & $\begin{array}{l}\text { A. austrina Small } \\
\text { A. dicolor Pursh } \\
\text { A. florida Bartram } \\
\text { A. humilis Loddiges ex Lindley } \\
\text { A. octandra var. discolor (Pursch) Rehder } \\
\text { A. pavia var. atrosanguinea Kirchner } \\
\text { A. pavia var. discolor (Pursh) Torrey \& A. Gray } \\
\text { A. pavia var. nana Dippel } \\
\text { A. pavia var. pendula (Loudon) Rehder } \\
\text { A. pavia var. whitleyi Rehder } \\
\text { A. splendens Sargent }\end{array}$ & & $16,30,61,67,74,75$ \\
\hline A. pavia L. (continued) & $\begin{array}{l}\text { Pavia americana Saint-Hilaire } \\
\text { P. atropurpurea Spach } \\
\text { P. glauca Rafinesque } \\
\text { P. humilis (Loddiges ex Lindley) G. Don ex Loudon } \\
\text { P. intermedia Spach } \\
\text { P. lindleyana Spach } \\
\text { P. livida Spach } \\
\text { P. longiflora Rafinesque } \\
\text { P. lucida Spach }\end{array}$ & & \\
\hline
\end{tabular}


Table 1. contd....

\begin{tabular}{|c|c|c|c|}
\hline Taxa & Synonyms & $\begin{array}{c}\text { Distribution (Native } \\
\text { Range) }\end{array}$ & $\begin{array}{l}\text { References for Chemi- } \\
\text { cal Studies }\end{array}$ \\
\hline & $\begin{array}{l}\text { P. michauxii Spach } \\
\text { P. mollis Rafinesque } \\
\text { P. octandra Miller } \\
\text { P. parviflora Rafinesque } \\
\text { P. punctata Rafinesque } \\
\text { P. rubra Lamarck } \\
\text { P. versicolor Spach } \\
\text { P. willdenowiana Spach }\end{array}$ & & \\
\hline A. sylvatica Bartram & $\begin{array}{l}\text { A. georgiana Sargent } \\
\text { A. georgiana var. lanceolata Sargent } \\
\text { A. georgiana var. pubescens Sargent } \\
\text { A. neglecta var. georgiana Sargent } \\
\text { A. neglecta var. lanceolata Sargent } \\
\text { A. neglecta var. tomentosa Sargent } \\
\text { A. sylvatica var. lanceolata (Sargent) Bartr. }\end{array}$ & & \\
\hline $\begin{array}{l}\text { Sect. Macrothyrsus (Spach) K. } \\
\text { Koch }\end{array}$ & & SE USA & \\
\hline A. parviflora Walter & $\begin{array}{l}\text { A. alba (Poir.) Rafinesque } \\
\text { A. macrostachya Michx. } \\
\text { A. macrostachys Pers. } \\
\text { A. odorata F. Dietr. } \\
\text { A. parviflora f. serotina Rehder } \\
\text { Macrothyrsus discolor Spach } \\
\text { M. odorata (F. Dietr.) Rafinesque } \\
\text { Nebropsis alba (Poir.) Rafinesque } \\
\text { Pavia alba Poir. } \\
\text { P. edulis Poit. ex DC. } \\
\text { P. macrostachya (Michx.) DC. } \\
\text { P. macrostachys (Pers.) Loisel. } \\
\text { P. parviflora (Walter) Rafinesque } \\
\text { Pawia parviflora (Walter) Kuntze }\end{array}$ & SE USA & $74,80,81$ \\
\hline
\end{tabular}

Note: * The taxon was not validly published.

\section{PHYTOCHEMISTRY}

Seeds of Aesculus are the plant materials often used for medicine in Eurasia and North America, and thus the seeds and fruits are the main targets for chemical investigations in the last several decades. To date, more than 210 compounds have been isolated and identified from Aesculus. These compounds include triterpenoids, triterpenoid glycosides (saponins), flavonoids, coumarins, carotenoids, long fatty chain compounds, and some other classes of compounds.

\section{Triterpenoids}

Triterpenoids from the genus Aesculus belong to pentacyclic triterpenoids and have multiple hydroxyl groups at $\mathrm{C}$ 3, C-15, C-16, C-21, C-22, C-24, and C-28. Their structures vary based on the substituents of hydroxyl at C-15 and C-24 as well as the number and type of acyl groups at C-16, C-21, $\mathrm{C}-22$, and C-28. To date, six triterpenoids (1-6) and 14 acyltriterpenoids (7-20) (Table 2) have been isolated and identified from the hydrolysate of the saponin mixtures extracted from the seeds of Aesculus. Aescigenin (1), a product of the acid hydrolysis of the saponin aescin from the seeds of $A$. hippocastanum, was the first triterpenoid reported [25]. Later, a number of triterpenoids (sapogenins) and acyltriterpenoids (prosapogenins) were isolated and identified from the acid and alkaline hydrolysates of the Aesculus saponin mixtures. These hydrolytic products include barringtogenol-D (2) [26], $\mathrm{R}_{1}$-barrigenol (4) [27], barringtogenol-C (6) [27], 21-O-tigloyl-22- $O$-angeloyl- $\mathrm{R}_{1}$-barrigenol (10) [27], 16- $O$-acetylprotoaescigenin (12) [28], 21- $O$-angeloylprotoaescigenin (13) [28], 28-O-angeloylprotoaescigenin (15) [28], and 21-O-angeloylbarringtogenol-C (18) [27] from $A$. hippocastanum; aescigenin (1), protoaescigenin (5), barringtogenol-C (6), 22-angeloyl- $\mathrm{R}_{1}$-barrigenol (9), 21-angeloylbarringtogenol-C (18), 21,22-diangeleylbarrintogenol-C (20) from $A$. indica [29]; 24-hydroxy- $\mathrm{R}_{1}$-barrigenol (3) [16], $\mathrm{R}_{1}$ barrigenol (4) [16], barringtogenol-C (6) [30], 21-O-angeloyl-24-hydroxy- $\mathrm{R}_{1}$-barrigenol (7) [30], 21-O-angeloylprotoaescigenin (13) [30], 22- $O$-angeloylprotoaescigenin (14) [30], 21, 22-O-diangeloylprotoaescigenin (16) [30], 21-O- 


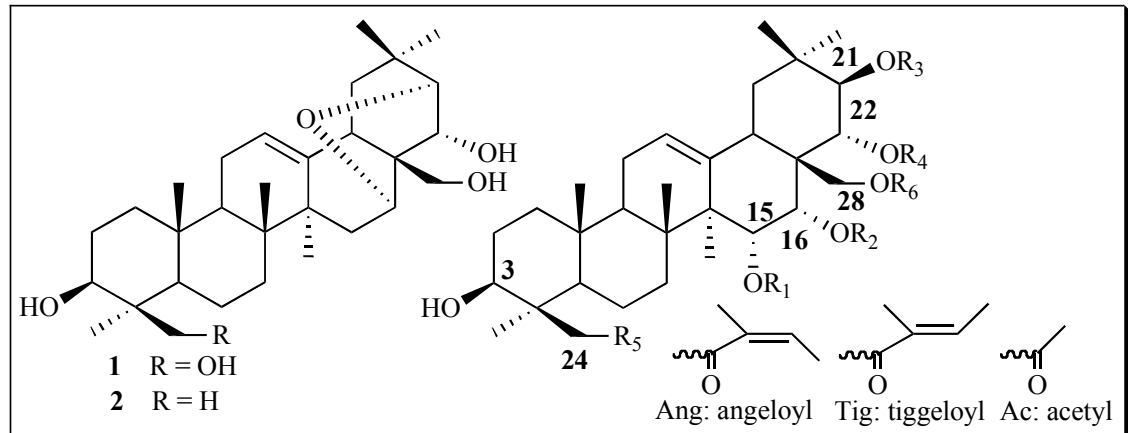

\begin{tabular}{|c|c|c|c|c|c|c|c|}
\hline Number & Name & $\mathbf{R}_{\mathbf{1}}$ & $\mathbf{R}_{\mathbf{2}}$ & $\mathbf{R}_{3}$ & $\mathbf{R}_{4}$ & $\mathbf{R}_{5}$ & $\mathbf{R}_{6}$ \\
\hline 5 & Protoaescigenin & $\mathrm{H}$ & $\mathrm{H}$ & $\mathrm{H}$ & $\mathrm{H}$ & $\mathrm{OH}$ & $\mathrm{H}$ \\
\hline 6 & Barringtogenol-C & $\mathrm{H}$ & $\mathrm{H}$ & $\mathrm{H}$ & $\mathrm{H}$ & $\mathrm{H}$ & $\mathrm{H}$ \\
\hline 8 & 21-O-angeloyl- $\mathrm{R}_{1}$-barrigenol & $\mathrm{OH}$ & $\mathrm{H}$ & Ang & $\mathrm{H}$ & $\mathrm{H}$ & $\mathrm{H}$ \\
\hline 9 & 22-O-angeloyl- $\mathrm{R}_{1}$-barrigenol & $\mathrm{OH}$ & $\mathrm{H}$ & $\mathrm{H}$ & Ang & $\mathrm{H}$ & $\mathrm{H}$ \\
\hline 10 & 21-O-tigloyl-22-O-angeloyl- $\mathrm{R}_{1}$-barrigenol & $\mathrm{OH}$ & $\mathrm{H}$ & Tig & Ang & $\mathrm{H}$ & $\mathrm{H}$ \\
\hline 11 & 21, 22-O-diangeloyl- $\mathrm{R}_{1}$-barrigenol & $\mathrm{OH}$ & $\mathrm{H}$ & Ang & Ang & $\mathrm{H}$ & $\mathrm{H}$ \\
\hline 14 & 22-O-angeloylprotoaescigenin & $\mathrm{H}$ & $\mathrm{H}$ & $\mathrm{H}$ & Ang & $\mathrm{OH}$ & $\mathrm{H}$ \\
\hline 15 & 28-O-angeloylprotoaescigenin & $\mathrm{H}$ & $\mathrm{H}$ & $\mathrm{H}$ & $\mathrm{H}$ & $\mathrm{OH}$ & Ang \\
\hline 16 & 21, 22-O-diangeloylprotoaescigenin & $\mathrm{H}$ & $\mathrm{H}$ & Ang & Ang & $\mathrm{OH}$ & $\mathrm{H}$ \\
\hline 17 & 21-O-tigloylbarringtogenol-C & $\mathrm{H}$ & $\mathrm{H}$ & Tig & $\mathrm{H}$ & $\mathrm{H}$ & $\mathrm{H}$ \\
\hline 18 & 21-O-angeloylbarringtogenol-C & $\mathrm{H}$ & $\mathrm{H}$ & Ang & $\mathrm{H}$ & $\mathrm{H}$ & $\mathrm{H}$ \\
\hline 19 & 28-O-tigloylbarringtogenol-C & $\mathrm{H}$ & $\mathrm{H}$ & $\mathrm{H}$ & $\mathrm{H}$ & $\mathrm{H}$ & Tig \\
\hline 20 & 21, 22-O-diangeloylbarringtogenol-C & $\mathrm{H}$ & $\mathrm{H}$ & Ang & Ang & $\mathrm{H}$ & $\mathrm{H}$ \\
\hline
\end{tabular}

Table 2. The Triterpenoids and Triterpenoid Saponins Reported in Various Taxa of Aesculus

\begin{tabular}{|c|c|c|c|c|c|c|c|c|c|}
\hline No. & Name & \multicolumn{2}{|c|}{ Sect. Aesculus } & \multicolumn{4}{|c|}{ Sect. Calothyrsus } & \multicolumn{2}{|c|}{ Sect. Pavia } \\
\hline 1 & Aescigenin & $25^{b}$ & & & & $34^{b}$ & $29^{b}$ & & \\
\hline 2 & Barringtogenol-D & 26 & & & & & & & \\
\hline 3 & 24-Hydroxy- $\mathrm{R}_{1}$-barrigenol & & & & & & & & $16^{b}$ \\
\hline 4 & $\mathrm{R}_{1}$-barrigenol & 27 & & & & & & & 16 \\
\hline 6 & Barringtogenol-C & 27 & & 33 & & & 29 & & 30 \\
\hline 7 & 21-O-angeloyl-24-hydroxy- $\mathrm{R}_{1}$-barrigenol & & & & & & & & 30 \\
\hline 8 & 21-O-angeloyl- $\mathrm{R}_{1}$-barrigenol & & & & & & & 31 & \\
\hline 9 & 22-O-angeloyl- $\mathrm{R}_{1}$-barrigenol & & & & & & 29 & 31 & \\
\hline
\end{tabular}


Table 2. contd....

\begin{tabular}{|c|c|c|c|c|c|c|c|c|c|}
\hline No. & Name & \multicolumn{2}{|c|}{ Sect. Aesculus } & \multicolumn{4}{|c|}{ Sect. Calothyrsus } & \multicolumn{2}{|c|}{ Sect. Pavia } \\
\hline 10 & 21-O-tigloyl-22-O-angeloyl- $\mathrm{R}_{1}$-barrigenol & 27 & & & & & & & \\
\hline 11 & 21, 22-O-diangeloyl- $\mathrm{R}_{1}$-barrigenol & & & & & & & 31 & \\
\hline 12 & 16-O-acetylprotoaescigenin & 28 & & & & & & & \\
\hline 15 & 28-O-angeloylprotoaescigenin & 28 & & & & & & & \\
\hline 16 & 21, 22-O-diangeloylprotoaescigenin & & & & & & & & 30 \\
\hline 17 & 21-O-tigloylbarringtogenol-C & & & & & & & & 30 \\
\hline 18 & 21-O-angeloylbarringtogenol-C & 28 & & & & & 29 & 31 & 30 \\
\hline 21 & Escin Ia & $26,38,39$ & 41 & & 46 & 51,52 & & & \\
\hline 22 & Escin Ib & $35,38,39$ & 41 & & 46 & 51,52 & & & \\
\hline 23 & Escin IIa & 38,39 & 42 & & & & & & \\
\hline 24 & Escin IIb & 38,39 & 42 & & & & & & \\
\hline 25 & Escin IIIa & 38,39 & & & & 51 & & & \\
\hline 26 & Escin IIIb & 40 & & & & & & & \\
\hline 27 & Escin IV & 40 & & & & & & & \\
\hline 28 & Escin IVc & & 44 & & 47 & 52 & & & \\
\hline 29 & Escin IVd & & & & 47 & 52 & & & \\
\hline 35 & Escin VI & 40 & & & & & & & \\
\hline 36 & Escin VIb & & & & 48 & & & & \\
\hline 37 & Deacetylescin Ia & & 43 & & & & & & \\
\hline 38 & Deacetylescin Ib & & 43 & & & 53 & 58 & & \\
\hline 39 & Deacetylescin IIa & & 43 & & & & & & \\
\hline 40 & Deacetylescin IIb & & 43 & & & & & & \\
\hline 41 & Desacylescin I & & 43 & & 48 & & & & \\
\hline 42 & Desacylescin II & & 43 & & & & & & \\
\hline 43 & Isoescin Ia & 40 & 44 & & 46 & 51,52 & & & \\
\hline 44 & Isoescin Ib & 40 & 44 & 60 & 46 & 51,52 & & & \\
\hline 45 & Isoescin IIa & & & & 49 & 51 & & & \\
\hline 46 & Isoescin IIb & & & & 49 & 51 & & & \\
\hline 47 & Isoescin IIIa & & & & 49 & 51 & & & \\
\hline 48 & Isoescin IIIb & & & & 49 & & & & \\
\hline 49 & Isoescin V & 40 & & & & & & & \\
\hline 50 & Isoescin VIa & & 45 & & & & & & \\
\hline
\end{tabular}


Table 2. contd....

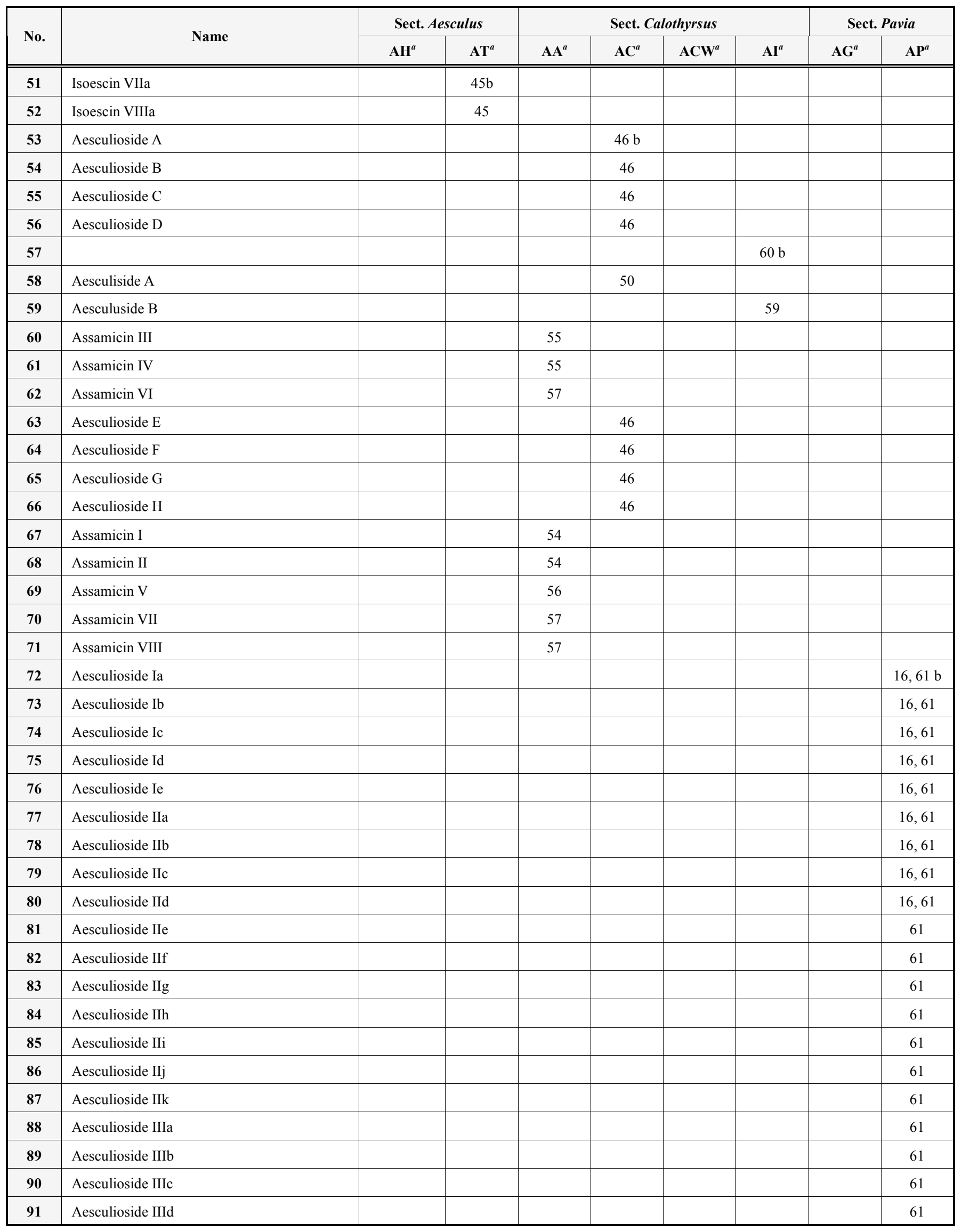


Table 2. contd....

\begin{tabular}{|c|c|c|c|c|c|c|c|c|c|}
\hline No. & Name & \multicolumn{2}{|c|}{ Sect. Aesculus } & \multicolumn{4}{|c|}{ Sect. Calothyrsus } & \multicolumn{2}{|c|}{ Sect. Pavia } \\
\hline 92 & Aesculioside IIIe & & & & & & & & 61 \\
\hline 93 & Aesculioside IIIf & & & & & & & & 61 \\
\hline 94 & Xanifolia-Y & & & & & & & & 61 \\
\hline 97 & Aesculioside IVb & & & & & & & & 16,61 \\
\hline 98 & & & & & & & & & 16,61 \\
\hline 99 & Aesculioside IVc & & & & & & & & 16,61 \\
\hline
\end{tabular}

${ }^{a} \mathrm{AH}:$ A. hippocastanum, AT: A. turbinata; $\mathrm{AA}:$ A. assamica; AC: A. chinensis; $\mathrm{ACW}:$ A. chinensis var. wilsonii; $\mathrm{AI}$ : A. indica; AG: A. glabra, AP: A. pavia. ${ }^{b}$ reference number.

tigloylbarringtogenol-C (17) [30], 21-O-angeloylbarringtogenol-C (18) [30], and 28-O-tigloylbarringtogenol-C (19) [30] from A. pavia; 21-angeloyl- $\mathrm{R}_{1}$-barrigenol (8), 22-O-angeloyl- $\mathrm{R}_{1}$-barrigenol (9), 21,22-O-diangeloyl- $\mathrm{R}_{1}$-barrigenol (11), 21-O-angeloylbarringtogenol-C (18), and 21,22-O-diangeloylbarringtogenol-C (20) from A. glabra [31]; protoaescigenin (5) [32], barringtogenol-C (6) [33], and 21-O-angyloylprotoescigenin (13) [32] from A. assamica; and aescigenin (1), protoaescigenin (5), and 21-O-angeloylprotoaescigenin (13) from A. chinensis var. wilsonii [34].

\section{Triterpenoid Glycosides (Triterpenoid Saponins)}

Triterpenoid glycosides or saponins are one of the main groups of chemical constituents from Aesculus. They are classified as polyhydroxylated triterpenoid glycosides based on four different aglycones (sapogenins), including 24hydroxy- $\mathrm{R}_{1}$-barrigenol (3), $\mathrm{R}_{1}$-barrigenol (4), protoaescigenin (5), and barringtogenol-C (6), due to the different substituents of hydroxyl at C-15 and C-24. To date, about 79 saponins have been isolated and identified from the genus Aesculus (Table 2). Most of the Aesculus saponins have a trisaccharide chain with a glucuronopyranosyl unit attached to the $\mathrm{C}-3$ position of the aglycone. A few saponins have a disaccharide chain at $\mathrm{C}-3$ of the sapogenin, such as assamicins V (69), VIII (71), aesculiosides Ie (76), and IId (80) while assamicins II (68), III (60), IV (61), and VI (62) are bisdesmosidic glycosides. The Aesculus type of saponins usually possesses acyl functions at C-21, C-22, and C-28 positions, some rarely, at $\mathrm{C}-16$, such as escin VIb (36). The acyl functions include angeloyl (Ang), tigloyl (Tig), acetyl (Ac), 2-methylbutanoyl (MB), and 2-methylpropanoyl (MP) groups.

The isolation and the structural determination of the individual ingredients in the saponin mixtures from the genus Aesculus have been the target of many investigations. The structures of two major saponins in aescin from the seeds of A. hippocastanum were first presumed as escins Ia (21) and $\mathrm{Ib}$ (22) on the basis of chemical and physicochemical evidences obtained by using the saponin mixture $[26,35]$. Then, the two major saponins were isolated from the commercial $\beta$-escin [36], and their MS data were reported based on the previous presumed structures [37]. The detailed phytochemical investigation of the saponins from A. hippocastanum was conducted by Yoshikawa's group [38-40]. A total of 12 saponins were isolated from the seeds of this species. The structures of these saponins were determined by extensive NMR and HRMS analysis as well as chemical degradation. These saponins are escins Ia (21) [38, 39], Ib (22) [38, 39], IIa (23) [38, 39], IIb (24) [38, 39], IIIa (25) [38, 39], IIIb (26) [40], IV (27) [40], V (34) [40], and VI (35) [40] and isoescins Ia (43) [40], Ib (44) [40], and V (49) [40].

The seeds of $A$. turbinata also contain rich triterpenoid saponins as the main components. A number of investigations on the seeds of Japanese horse chestnut resulted in the isolation and structure determination of 16 polyhydroxylated triterpenoid saponins. These saponins are escins Ia (21) [41], Ib (22) [41], IIa (23) [42], and IIb (24) [42]; deacetylescins Ia (37), Ib (38), IIa (39), and IIb (40) [43]; desacylescins I (41) and II (42) [43]; escin IVc (28) [44]; isoescin Ia (43) [44], Ib (44) [44], VIa (50) [45], VIIa (51) [45], and VIIIa (52) [45].

Of the section Calothyrsus, A. chinensis var. chinensis has been well investigated. The triterpenoid saponins, occurring as a complex mixture in the seeds of A. chinensis var. chinensis, had not been investigated until 1999, when two groups of researchers reported a number of novel saponins. The first group reported four pair of new geometrical isomer saponins from the plant, named aesculiosides A-H (53-56, 63-66), with two pair of known compounds, escins Ia (21), and $\mathrm{Ib}(\mathbf{2 2})$ and isoescins $\mathrm{Ia} \mathrm{(43)}$ and $\mathrm{Ib}(\mathbf{4 4})$ [46]. The second group reported four new saponins escins IVc (28), IVd (29), IVe (30), and IVf (31) [47]. The structures of these novel saponins were determined by extensive NMR, HRMS, and $\mathrm{x}$-ray analyses, as well as chemical degradation. Later, from 2001 to 2004, more Aesculus polyhydroxylated triterpenoid saponins were isolated and identified from the seeds of A. chinensis var. chinensis. These saponins include escins IVg (32), IVh (33), and VIb (36) [48]; desacylescin I (41) [48]; isoescins IIa (45), IIb (46), IIIa (47), and IIIb (48) [49]; and aesculiside A (58) [50]. Escins Ia (21), Ib (22), IIIa (25), isoescins Ia (43), Ib (44), IIa (45), IIb (46), and IIIa (47) were isolated and identified from A. chinensis var. wilsonii [51]. Aesculus chinensis Bunge var. chekiangensis (Hu \& W.P. Fang) W.P. Fang was described based on cultivated plants and is now recognized as the synonym of $A$. chinensis var. wilsonii [14]. Its seeds, also called "Sha Luo Zhi" in 


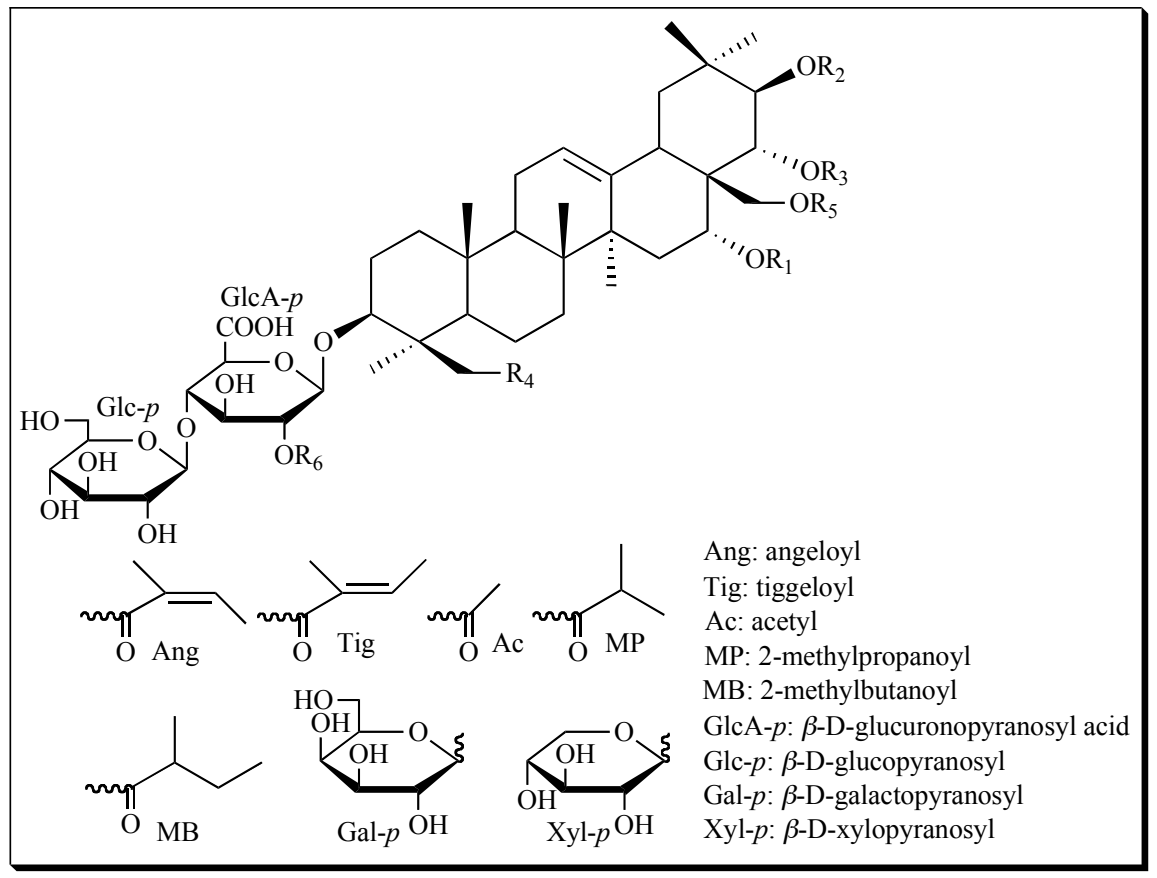

\begin{tabular}{|c|c|c|c|c|c|c|c|}
\hline No. & Name & $\mathbf{R}_{1}$ & $\mathbf{R}_{\mathbf{2}}$ & $\mathbf{R}_{3}$ & $\mathbf{R}_{4}$ & $\mathbf{R}_{5}$ & $\mathbf{R}_{6}$ \\
\hline 21 & Escin Ia & $\mathrm{H}$ & Tig & Ac & $\mathrm{OH}$ & $\mathrm{H}$ & Gle $-p$ \\
\hline 22 & Escin Ib & $\mathrm{H}$ & Ang & $\mathrm{Ac}$ & $\mathrm{OH}$ & $\mathrm{H}$ & Gle- $p$ \\
\hline 23 & Escin IIa & $\mathrm{H}$ & Tig & $\mathrm{Ac}$ & $\mathrm{OH}$ & $\mathrm{H}$ & Xyl- $p$ \\
\hline 24 & Escin IIb & $\mathrm{H}$ & Ang & $\mathrm{Ac}$ & $\mathrm{OH}$ & $\mathrm{H}$ & $\mathrm{Xyl}-p$ \\
\hline 25 & Escin IIIa & $\mathrm{H}$ & Tig & $\mathrm{Ac}$ & $\mathrm{H}$ & $\mathrm{H}$ & Gal $-p$ \\
\hline 26 & Escin IIIb & $\mathrm{H}$ & Ang & $\mathrm{Ac}$ & $\mathrm{H}$ & $\mathrm{H}$ & Gal- $p$ \\
\hline 27 & Escin IV & $\mathrm{H}$ & Ac & Ac & $\mathrm{OH}$ & $\mathrm{H}$ & Glc- $p$ \\
\hline 28 & Escin IVc & $\mathrm{H}$ & $\mathrm{H}$ & Tig & $\mathrm{OH}$ & Ac & Gle- $p$ \\
\hline 29 & Escin IVd & $\mathrm{H}$ & $\mathrm{H}$ & Ang & $\mathrm{OH}$ & Ac & Gle- $p$ \\
\hline 30 & Escin IVe & $\mathrm{H}$ & $\mathrm{H}$ & $\mathrm{H}$ & $\mathrm{OH}$ & Tig & Glc- $p$ \\
\hline 31 & Escin IVf & $\mathrm{H}$ & $\mathrm{H}$ & $\mathrm{H}$ & $\mathrm{OH}$ & Ang & Glc- $p$ \\
\hline 32 & Escin IVg & $\mathrm{H}$ & $\mathrm{H}$ & Tig & $\mathrm{OH}$ & $\mathrm{H}$ & Gle- $p$ \\
\hline 33 & Escin IVh & $\mathrm{H}$ & $\mathrm{H}$ & Ang & $\mathrm{OH}$ & $\mathrm{H}$ & Glc- $p$ \\
\hline 34 & Escin V & $\mathrm{H}$ & MP & $\mathrm{Ac}$ & $\mathrm{OH}$ & $\mathrm{H}$ & Glc- $p$ \\
\hline 35 & Escin VI & $\mathrm{H}$ & MB & Ac & $\mathrm{OH}$ & $\mathrm{H}$ & Glc- $p$ \\
\hline 36 & Escin VIb & Ang & Ac & $\mathrm{H}$ & $\mathrm{OH}$ & $\mathrm{H}$ & Glc- $p$ \\
\hline 37 & Deacetylescin Ia & $\mathrm{H}$ & Tig & $\mathrm{H}$ & $\mathrm{OH}$ & $\mathrm{H}$ & Glc- $p$ \\
\hline 38 & Deacetylescin Ib & $\mathrm{H}$ & Ang & $\mathrm{H}$ & $\mathrm{OH}$ & $\mathrm{H}$ & Glc- $p$ \\
\hline 39 & Deacetylescin IIa & $\mathrm{H}$ & Tig & $\mathrm{H}$ & $\mathrm{OH}$ & $\mathrm{H}$ & Xyl- $p$ \\
\hline 40 & Deacetylescin IIb & $\mathrm{H}$ & Ang & $\mathrm{H}$ & $\mathrm{OH}$ & $\mathrm{H}$ & $\mathrm{Xyl}-p$ \\
\hline 41 & Desacylescin I & $\mathrm{H}$ & $\mathrm{H}$ & $\mathrm{H}$ & $\mathrm{OH}$ & $\mathrm{H}$ & Glc- $p$ \\
\hline 42 & Desacylescin II & $\mathrm{H}$ & $\mathrm{H}$ & $\mathrm{H}$ & $\mathrm{OH}$ & $\mathrm{H}$ & $\mathrm{Xyl}-p$ \\
\hline 43 & Isoescin Ia & $\mathrm{H}$ & Tig & $\mathrm{H}$ & $\mathrm{OH}$ & $\mathrm{Ac}$ & Glc $-p$ \\
\hline
\end{tabular}


Compound 21-62. contd....

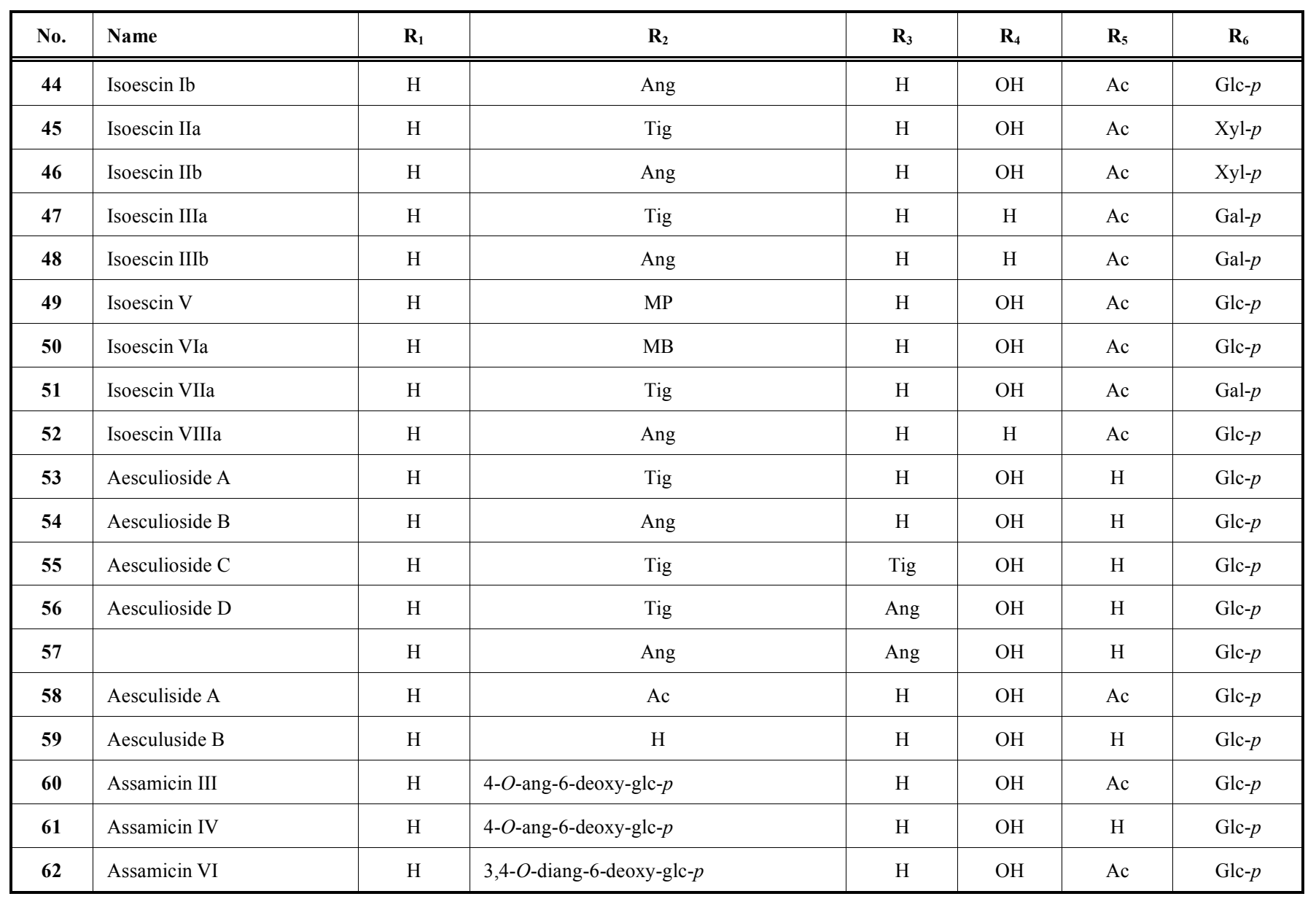

traditional Chinese medicines, have the same medicinal value [11]. A number of saponins including escins Ia (21) [52], Ib (22) [52], IVc (28) [52], IVd (29) [52], IVe (30) [53], IVh (33) [53], aesculuside A (deacetylescin Ib, 38) [53], isoescins Ia (43) [52] and $\mathrm{Ib}(44)$ [52] were isolated and identified from the seeds of this variety. Except aesculuside A (38), all saponins isolated from $A$. chinensis var. chekiangensis were also found in the seeds of A. chinensis var. chinensis.

The saponins from other species of the section Calothyrsus were also reported. Interestingly, some unique saponins including assamicins I (67) [54], II (68) [54], III (60) [55], IV (61) [55], V (69) [56], VI (62) [57], VII (70) [57], and VIII (71) [57] were isolated and identified from $A$. assamica, together with a known saponin isoescin $\mathrm{Ib}(\mathbf{4 4})$. In addition, aesculusides A (deacetylescin Ib, 38) [58], B (59) [59], and 3 - $O$ - $[\beta$-D-glucopyranosyl- $(1 \rightarrow 2)]$ - $[\beta$-D-glucopyranosyl$(1 \rightarrow 4)]$ - $\beta$-D-glucuronopyranosyl-21,22-O-diangeloyl-

$3 \beta, 16 \alpha, 21 \beta, 22 \alpha, 24 \beta, 28$-heptahydroxyolean-12-ene (57) [56] were isolated from $A$. indica.

The investigation of saponins from section Pavia is limited to A. pavia. Recently, a detailed phytochemical investigation of the saponins occurring as a very complex mixture from the fruits of A. pavia located in Nacogdoches (Texas, USA) resulted in the isolation and discovery of 25 new saponins, named as aesculiosides Ia-Ie (72-76), IIa-IIK (77-
87), IIIa-IIIf (88-93), and IVa-IVc $(\mathbf{9 5}, 97,99)$, together with three known saponins 3-O-[ $\beta$-D-galactopyranosyl$(1 \rightarrow 2)]$-[ $\alpha$-L-arabinofuranosyl- $(1 \rightarrow 3)]-\beta$-D-glucuronopyranosyl-21,22-O-diangeloyl-3 $\beta, 15 \alpha, 16 \alpha, 21 \beta, 22 \alpha, 28$-hexahydroxyolean-12-ene (xanifolia-Y, 94), 3- $O$-[ $\beta$-D-glucopyranosyl- $(1 \rightarrow 2)]$ - $[\alpha$-L-arabinofuranosyl- $(1 \rightarrow 3)]-\beta$-D-glucuronopyranosyl-21,22-O-diangeloyl-3 $\beta, 16 \alpha, 21 \beta, 22 \alpha, 24 \beta, 28$ hexahydroxyolean-12-ene (96), and 3-O-[ $\beta$-D-galactopyranosyl- $(1 \rightarrow 2)]$-[ $a$-L-arabinofuranosyl- $(1 \rightarrow 3)]-\beta$-D-glucuronopyranosyl-21,22-O-diangeloyl-3 $\beta, 16 \alpha, 21 \beta, 22 \alpha, 28$ pentahydroxyolean-12-ene (98) [16,61].

The polyhydroxylated triterpenoid saponins from the genus Aesculus share a common oligosaccharide chain with a glucuronopyranosyl unit attached to C-3 of the aglycone, although the components and sequences of the oligosaccharides are different, Interestingly the type of the monosaccharide linked to $\mathrm{C}-2$ of the glucuronopyranosyl unit in the oligosaccharide chain for the most of saponins (21-50, 53-68) is related to the substituent at C-24 of aglycone. Specifically, the saponins possessed the aglycones of 24-hydroxy- $\mathrm{R}_{1}$ barrigenol (3) or protoaescigenin (5) with a hydroxyl group at C-24 had a glucopyranosyl or xylopyranosyl unit attached to $\mathrm{C}-2$ of the glucuronopyranosyl unit while a galactopyranosyl unit linked to $\mathrm{C}-2$ of the glucuronopyranosyl unit was found in the saponins with the aglycones of $\mathrm{R}_{1}$ barrigenol (4) or barringtogenol-C (6) without the hydroxyl group at C-24. Isoescins VIIa (51), VIIIa (52), and assamicin 

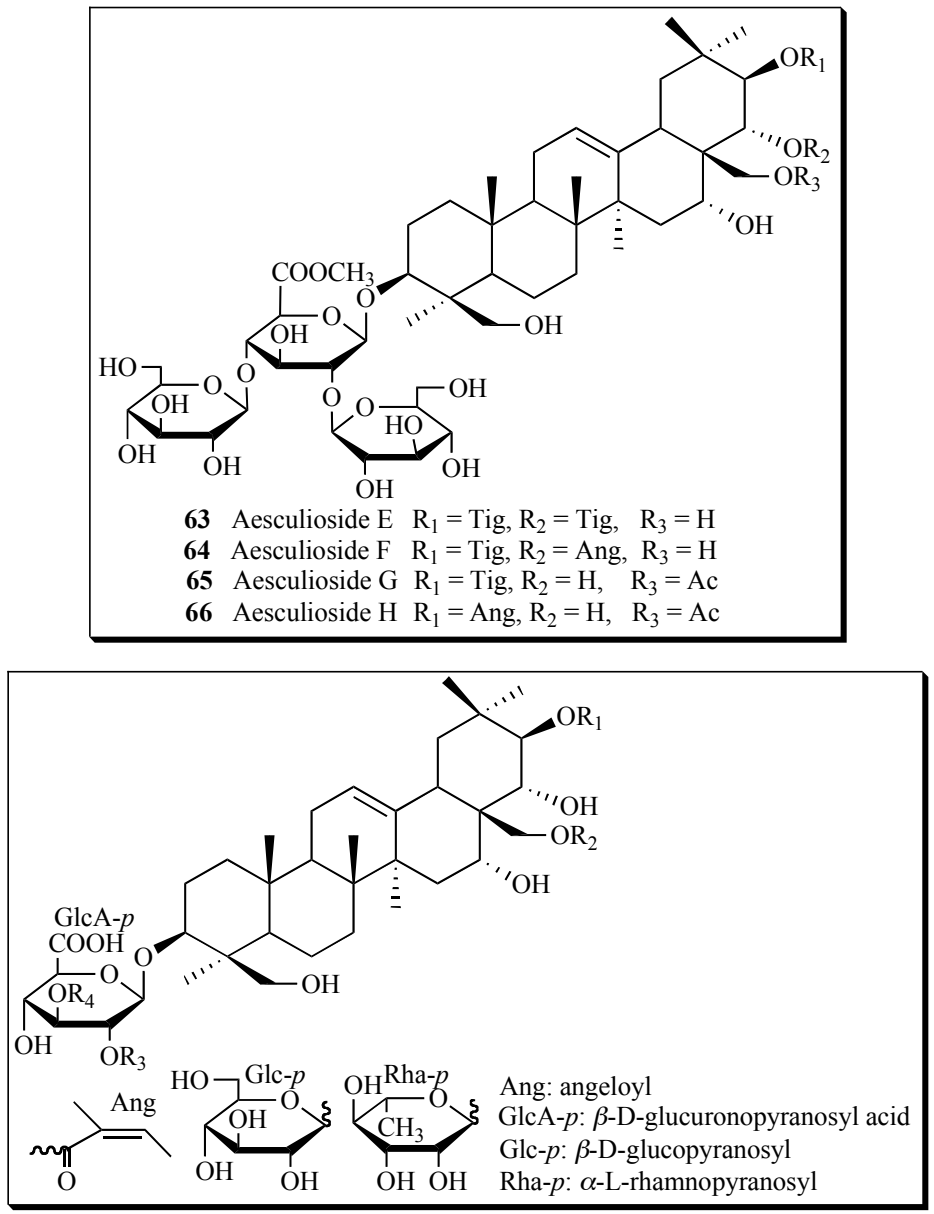

\begin{tabular}{|c|c|c|c|c|c|}
\hline No. & Name & $\mathbf{R}_{\mathbf{1}}$ & $\mathbf{R}_{\mathbf{2}}$ & $\mathbf{R}_{\mathbf{3}}$ & $\mathbf{R}_{\mathbf{4}}$ \\
\hline \hline $\mathbf{6 7}$ & Assamicin I & Ang & Ac & Glc- $p$ & Rha- $p$ \\
\hline $\mathbf{6 8}$ & Assamicin II & 3,4-O-diangeloyl-6-deoxy-glc- $p$ & Ac & D-Glc- $p$ & Rha- $p$ \\
\hline $\mathbf{6 9}$ & Assamicin V & Ang & H & Rha- $p$ \\
\hline $\mathbf{7 0}$ & Assamicin VII & Ang & Rha- $p$ & Glc- $p$ \\
\hline $\mathbf{7 1}$ & Assamicin VIII & Ang & H & H & Glc- $p$ \\
\hline
\end{tabular}

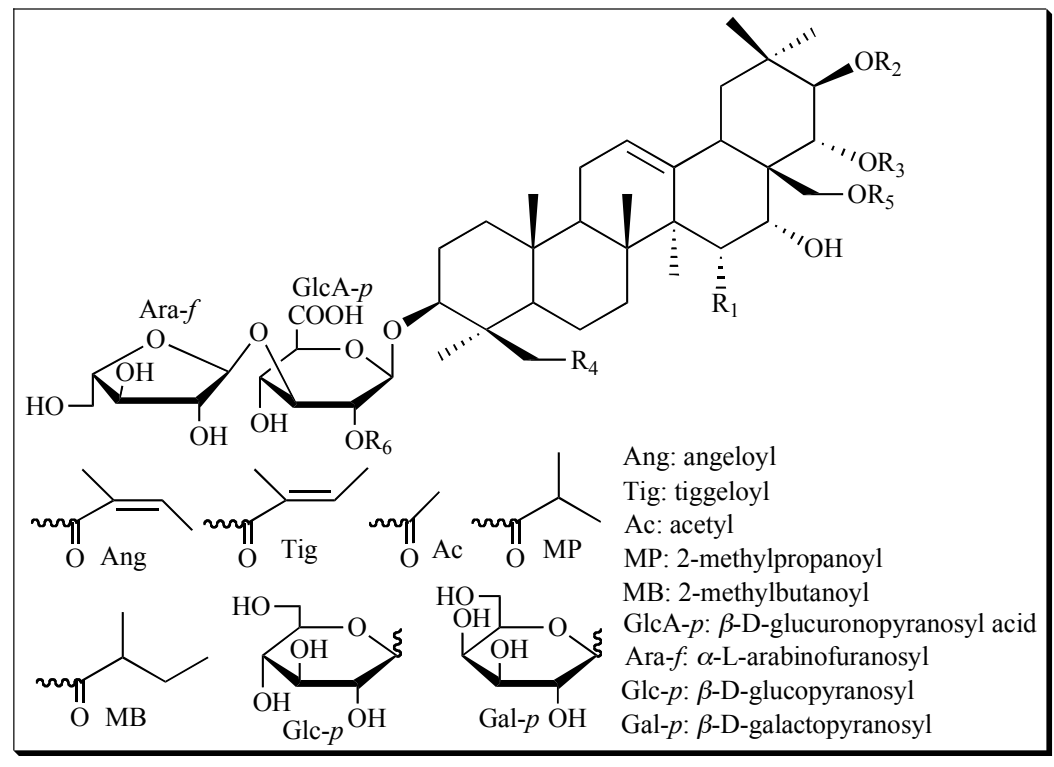


Compounds 72-99. contd....

\begin{tabular}{|c|c|c|c|c|c|c|c|}
\hline No. & Name & $\mathbf{R}_{1}$ & $\mathbf{R}_{2}$ & $\mathbf{R}_{3}$ & $\mathbf{R}_{4}$ & $\mathbf{R}_{5}$ & $\mathbf{R}_{6}$ \\
\hline 72 & Aesculioside Ia & $\mathrm{OH}$ & $\mathrm{H}$ & $\mathrm{H}$ & $\mathrm{H}$ & $\mathrm{H}$ & Gal- $p$ \\
\hline 73 & Aesculioside Ib & $\mathrm{OH}$ & $\mathrm{H}$ & $\mathrm{H}$ & $\mathrm{OH}$ & $\mathrm{H}$ & Glc- $p$ \\
\hline 74 & Aesculioside Ic & $\mathrm{H}$ & $\mathrm{H}$ & $\mathrm{H}$ & $\mathrm{H}$ & $\mathrm{H}$ & Gal- $p$ \\
\hline 75 & Aesculioside Id & $\mathrm{H}$ & $\mathrm{H}$ & $\mathrm{H}$ & $\mathrm{OH}$ & $\mathrm{H}$ & Glc- $p$ \\
\hline 76 & Aesculioside Ie & $\mathrm{H}$ & $\mathrm{H}$ & $\mathrm{H}$ & $\mathrm{OH}$ & $\mathrm{H}$ & $\mathrm{H}$ \\
\hline 77 & Aesculioside IIa & $\mathrm{OH}$ & Ang & $\mathrm{H}$ & $\mathrm{H}$ & $\mathrm{H}$ & Gal- $p$ \\
\hline 78 & Aesculioside IIb & $\mathrm{H}$ & Ang & $\mathrm{H}$ & $\mathrm{OH}$ & $\mathrm{H}$ & Glc- $p$ \\
\hline 79 & Aesculioside IIc & $\mathrm{H}$ & Ang & $\mathrm{H}$ & $\mathrm{H}$ & $\mathrm{H}$ & Gal- $p$ \\
\hline 80 & Aesculioside IId & $\mathrm{H}$ & Ang & $\mathrm{H}$ & $\mathrm{OH}$ & $\mathrm{H}$ & $\mathrm{H}$ \\
\hline 81 & Aesculioside IIe & $\mathrm{OH}$ & Tig & Ac & $\mathrm{OH}$ & $\mathrm{H}$ & Glc- $p$ \\
\hline 82 & Aesculioside IIf & $\mathrm{OH}$ & Tig & Ac & $\mathrm{H}$ & $\mathrm{H}$ & Gal- $p$ \\
\hline 83 & Aesculioside IIg & $\mathrm{OH}$ & Ang & Ac & $\mathrm{H}$ & $\mathrm{H}$ & Gal- $p$ \\
\hline 84 & Aesculioside IIh & $\mathrm{H}$ & Tig & Ac & $\mathrm{OH}$ & $\mathrm{H}$ & Glc- $p$ \\
\hline 85 & Aesculioside IIi & $\mathrm{H}$ & Ang & Ac & $\mathrm{OH}$ & $\mathrm{H}$ & Glc- $p$ \\
\hline 86 & Aesculioside IIj & $\mathrm{H}$ & Tig & Ac & $\mathrm{H}$ & $\mathrm{H}$ & Gal- $p$ \\
\hline 87 & Aesculioside IIk & $\mathrm{H}$ & Ang & Ac & $\mathrm{H}$ & $\mathrm{H}$ & Gal- $p$ \\
\hline 88 & Aesculioside IIIa & $\mathrm{H}$ & Ang & $\mathrm{H}$ & $\mathrm{OH}$ & Ac & Glc- $p$ \\
\hline 89 & Aesculioside IIIb & $\mathrm{OH}$ & Ang & MP & $\mathrm{OH}$ & $\mathrm{H}$ & Glc- $p$ \\
\hline 90 & Aesculioside IIIc & $\mathrm{OH}$ & Tig & MP & $\mathrm{H}$ & $\mathrm{H}$ & Gal- $p$ \\
\hline 91 & Aesculioside IIId & $\mathrm{OH}$ & Tig & Tig & $\mathrm{OH}$ & $\mathrm{H}$ & Glc- $p$ \\
\hline 92 & Aesculioside IIIe & $\mathrm{OH}$ & Tig & Ang & $\mathrm{OH}$ & $\mathrm{H}$ & Glc- $p$ \\
\hline 93 & Aesculioside IIIf & $\mathrm{OH}$ & Tig & Tig & $\mathrm{H}$ & $\mathrm{H}$ & Gal- $p$ \\
\hline 94 & Xanifolia-Y & $\mathrm{OH}$ & Ang & Ang & $\mathrm{H}$ & $\mathrm{H}$ & Gal- $p$ \\
\hline 95 & Aesculioside IVa & $\mathrm{OH}$ & Ang & MB & $\mathrm{H}$ & $\mathrm{H}$ & Gal- $p$ \\
\hline 96 & & $\mathrm{H}$ & Ang & Ang & $\mathrm{OH}$ & $\mathrm{H}$ & Glc- $p$ \\
\hline 97 & Aesculioside IVb & $\mathrm{H}$ & Ang & MB & $\mathrm{OH}$ & $\mathrm{H}$ & Glc- $p$ \\
\hline 98 & & $\mathrm{H}$ & Ang & Ang & $\mathrm{H}$ & $\mathrm{H}$ & Gal- $p$ \\
\hline 99 & Aesculioside IVc & $\mathrm{H}$ & Ang & MB & $\mathrm{H}$ & $\mathrm{H}$ & Gal- $p$ \\
\hline
\end{tabular}

VII (70) are the only three saponins that exhibit exceptions to this structural configuration.

The saponins from the five Eurasian taxa, including $A$. hippocastanum, A. chinensis var. chinensis, $A$. chinensis var. wilsonii, A. turbinata, and $A$. indica discussed above (Table 2), were structurally based on two aglycones of protoaescigenin (5) and barringtogenol-C (6) with a trisaccharide chain at $\mathrm{C}-3$ position of the aglycone. This trisaccharide chain has a glucopyranosyl unit attached to $\mathrm{C}-4$ of the glucuronopyranosyl unit, which is linked to $\mathrm{C}-3$ of the aglycone. The aglycones of the saponins from the North America species $A$. pavia are more variable with four different aglycones, in- cluding 24-hydroxy- $\mathrm{R}_{1}$-barrigenol (3), $\mathrm{R}_{1}$-barrigenol-C (4), protoaescigenin (5) and barringtogenol-C (6). These saponins (72-99) from A. pavia have an oligosaccharide chain at $\mathrm{C}-3$ of the aglycone with an arabinofuranosyl unit affixed to C-3 of the glucuronopyranosyl unit instead. This significant chemical difference represents a variable chemotaxonomic feature and may be the basis for different medicinal uses between North American and Eurasian Aesculus species. This result also supports a conclusion drawn from phenotypic and DNA sequence analyses that eastern North American species of Aesculus represent a different evolutionary lineage that diverged early from their Eurasian counterparts $[1,4,13]$. 
It is also worth mentioning that assamicins I (67), II (68), III (60), IV (61), V (69), VI (62), VII (70), and VIII (71) from $A$. assamica have different components and sequences of the oligosaccharide chain at C-3 from the saponins isolated from the other Aesculus species. Some of assamicin saponins $(60,61,62$, and 68) have two oligosaccharide moieties attached to $\mathrm{C}-3$ and $\mathrm{C}-21$ of the aglycone.

\section{Flavonoids}

Flavonoids and their derivatives are also one of the main components of the genus Aesculus. A total of 49 flavonoids including flavonols and their glycosides (100-126), flavanones, and flavanone derivatives (127-148) were isolated and identified from the seeds of Aesculus. The glycosides of quercetin (100) and kaempferal (116) with an oligosaccharide chain at C-3 or two oligosaccharide chains at C-3 and C-3' are types of flavonol glycosides while flavanone derivatives are characterized as one of two types of proanthocyanidin and polymerized epicatechin.

A few early investigations led to the isolation and identification of rutin (111), quercitrin (113), and astragalin (122) from $A$. indica $[62,63]$ and quercetin (100) and kaempferal (116) from $A$. assamica [33].

The flavonols and their glycosides from the seeds of $A$. hippocastanum have been well documented. Two investigations on the seeds of this species resulted in the isolation and structural determination of 15 flavonols and their glycosides $[64,65]$. These compounds are quercetin 3-O-[ $\beta$-D-xylopyranosyl- $(1 \rightarrow 2)]$-[O- $\beta$-D-glucopyranosyl- $(1 \rightarrow 3)]-O-\beta$-D-glucopyranosyl-3'-O- $\beta$-D-glucopyranoside (101), tamarixetin 3$O$-[ $\beta$-D-xylopyranosyl- $(1 \rightarrow 2)]-[O-\beta$-D-glucopyranosyl$(1 \rightarrow 3)]-O-\beta$-D-glucopyranosyl-3'-O- $\beta$-D-glucopyranoside (102), quercetin $3-O-\beta$-D-xylopyranosyl- $(1 \rightarrow 2)-O-\beta$-Dglucopyranosyl-3'-O- $\beta$-D-glucopyranoside (104), quercetin 3 - $O$ - $[\beta$-D-xylopyranosyl- $(1 \rightarrow 2)]$ - $[O-\beta$-D-glucopyranosyl$(1 \rightarrow 3)]-O-\beta$-D-glucopyranoside (106), quercetin $3-O-\beta$-Dxylopyranosyl- $(1 \rightarrow 2)-O$ - $\beta$-D-glucopyranosyl- $(1 \rightarrow 3)-O-\beta$-Dglucopyranoside (107), tamarixetin 3- $O$ - $[\beta$-D-xylopyranosyl$(1 \rightarrow 2)]$ - $[O-\beta$-D-glucopyranosyl- $(1 \rightarrow 3)]-O-\beta$-D-glucopyranoside (108), quercetin 3-O- $\beta$-D-xylopyranosyl- $(1 \rightarrow 2)-O-\beta$ $\mathrm{D}$-glucopyranoside (109), quercetin $3-O-\beta$-D-xylopyranosyl$(1 \rightarrow 4)-O$ - $\alpha$-L-rhamnopyranoside (multinoside A, 110), quercetin $3-O-\beta$-D-xylopyranosyl- $(1 \rightarrow 2)-O-\beta$-D-glucopyranosyl-3'- $O$-[nicotynoyl- $(1 \rightarrow 6)]-\beta$-D-glucopyranoside (124), quercetin $3-O-\beta$-D-xylopyranosyl- $(1 \rightarrow 2)-O-\beta$-D-glucopyranosyl-3'- $O$-[indolin-2-on-3-hydroxy-3-acetyl- $(1 \rightarrow 6)]-\beta$-Dglucopyranoside (125), quercetin 3-O- $\beta$-D-xylopyranosyl$(1 \rightarrow 2)-O$ - $\beta$-D-glucopyranosyl-3'- $O$-[indolin-2-on-3-acetyl$(1 \rightarrow 6)]$ - $\beta$-D-glucopyranoside (126), kaempferal 3- $O$-[ $\beta$-Dxylopyranosyl- $(1 \rightarrow 2)]-[O-\beta$-D-glucopyranosyl- $(1 \rightarrow 3)]-O-\beta$ D-glucopyranoside (118), kaempferal 3-O- $\beta$-D-xylopyranosyl-( $1 \rightarrow 2)-O$ - $\beta$-D-glucopyranosyl- $(1 \rightarrow 3)-O$ - $\beta$-D-glucopyranoside (119), kaempferal $3-O-\beta$-D-xylopyranosyl-( $1 \rightarrow 2)$ $O$ - $\beta$-D-glucopyranoside (leucoside, 120), and kaempferal 3$O$ - $\beta$-D-xylopyranosyl- $(1 \rightarrow 4)-O$ - $\alpha$-L-rhamnopyranoside(multiflorine $\mathrm{B}, \mathbf{1 2 1}$ ).

The seeds of $A$. chinensis var. chinensis are rich in flavonoids. A number of flavonoid glycosides were isolated from the seeds of this species. These flavonoids were identified as quercetin 3-O-[ $\beta$-D-xylopyranosyl- $(1 \rightarrow 2)]-[\alpha-\mathrm{L}$ rhamnopyranosyl-( $1 \rightarrow 6)]$ - $\beta$-D-glucopyranosyl-3'- $\beta$-D-glu- copyranoside (aescuflavoside, 103), quercetin $3-O-\beta$-Dxylopyranosyl- $(1 \rightarrow 2)$ - $\beta$-D-glucopyranosyl-3'- $\beta$-D-glucopyranoside (104), tamarixetin $3-O-\beta$-D-xylopyranosyl- $(1 \rightarrow 2)$ $\beta$-D-glucopyranosyl-3'- $O$ - $\beta$-D-glucopyranoside (aescuflavoside $\mathrm{A}, 105)$, quercetin $3-O-\beta$-D-xylopyranosyl- $(1 \rightarrow 2)-\beta$ D-glucopyranoside (109), quercetin 3- $O-\beta$-D-glucopyranoside (isoquercitrin, 112), kaempferal $3-O-[\beta$-D-xylopyranosyl$(1 \rightarrow 2)]$-[ $\beta$-D-glucopyranosyl- $(1 \rightarrow 6)]-\beta$-D-glucopyranoside (117), kaempferal 3-O- $\beta$-D-xylopyranosyl- $(1 \rightarrow 2)-\beta$-Dglucopyranoside (leucoside, 120), kaempferal $3-O-\beta$-Dglucopyranosyl- $(1 \rightarrow 4)$ - $\alpha$-L-rhamnopyranoside (multiflorine $\mathrm{B}$, 121), kaempferal-3- $O-\beta$-D-glucopyranoside (astragalin, 122), and kaempferal-3- $O-\beta$-D-galactopyranoside (trifolin, 123) [66].

Three known flavonoid glycosides quercetin 3-O- $\alpha-\mathrm{L}-$ rhamnopyranoside (quercitrin, 113), quercetin 3-O- $\alpha$-Larabinopyranoside (114), and isorhamnetin 3- $O-\alpha-\mathrm{L}-$ arabinoside (distichin, 115) were recently isolated and identified from the leaves of $A$. pavia, grown in Italy [67].

In addition, some flavanone derivatives were also identified from Aesculus species. These compounds include (-)epicatechin (127) from the seeds of A. californica [68]; proanthocyanidins A-2 (131), A-4 (132), A-6 (134), A-7 (135), B-2 (130), B-5 (133), C-1 (137), epicatechin- $(4 \beta \rightarrow 6)$ epicatechin- $(4 \beta \rightarrow 6)$-epicatechin $(\mathbf{1 3 9})$, cinnamtannins $B_{1}$ (136), $B_{2}$ (138), aesculitannins A (140), B (141), C (142), D (143), E (144), F (145), G (146) [69], and leucocyanidine (128) [70] from the seeds of A. hippocastanum; and three docyl sulfide derivatives of (-)-epicatechin (129) and proanthocyanidins $(147,148)$ from the seeds of $A$. turbinata [19].

\section{Coumarins}

Coumarins isolated from Aesculus usually have simple structures. The main coumarins are esculetin (150), fraxetin (151), fraxin (156), and aesculin (157) from A. turbinata [71, 72]; umbelliferone (149), esculetin (150), scopoletin (152), isoscopoletin (153), skimin (154), chikhorin (155), fraxin (156), aesculin (157), scopolin (158), and isoscopolin (159) from A. hippocastanum [73]; and scopolin (158) and 5methoxyscopolin (160) from A. pavia [61]. Recently, a new prenylated coumarin with antifungal activity, pavietin (161), was isolated and identified from the leaves of A. pavia [67].

\section{Carotenoids}

Twenty-one carotenoids have been identified from Aesculus. An early investigation on the leaves and pollen of the three species A. turbinata, A. pavia, and A. parviflora by HPLC analysis indicated the presence of seven carotenoids $\beta$-carotene (162), zeaxanthin (163), $\alpha$-carotene (167), lutein (168), capsanthin (176), capsanthin 5,6-epoxide (177), and capsorubin (178) [74]. A high concentration of $\alpha$-carotene was found in the leaves and keto hydroxyl carotenoids with a pentanuclear ring structure (capsanthin, capsanthin 5,6epoxide, and capsorubin) were identified in the pollen. These keto hydroxyl carotenoids were proposed to have special chemotaxonomic significance for the genus Aesculus. Later, in 2000, 16 carotene derivatives were detected in buds, pollen, and petals of $A$. hippocastanum and A. pavia by HPLC analysis with a diode array detector utilizing authentic samples as the references. These carotenoids are $\beta$-carotene (162), $\beta$-cryptoxanthin (164), violaxanthin (165), 9-cis- 


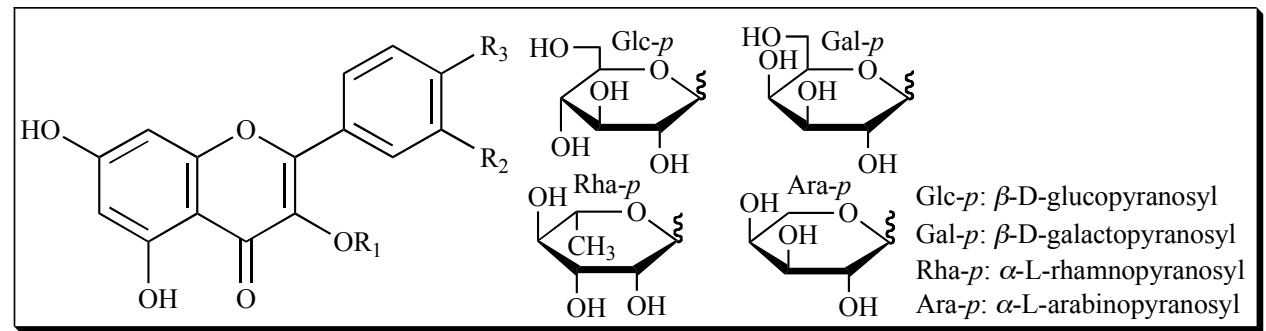

\begin{tabular}{|c|c|c|c|c|}
\hline Number & Name & $\mathbf{R}_{\mathbf{1}}$ & $\mathbf{R}_{\mathbf{2}}$ & $\mathbf{R}_{3}$ \\
\hline 101 & & {$[\mathrm{Xyl}(1 \rightarrow 2)][\mathrm{Glc}(1 \rightarrow 3)] \mathrm{Glc}$} & O-Glc & $\mathrm{OH}$ \\
\hline 102 & & {$[\mathrm{Xyl}(1 \rightarrow 2)][\mathrm{Glc}(1 \rightarrow 3)] \mathrm{Glc}$} & O-Glc & $\mathrm{OCH}_{3}$ \\
\hline 103 & Aescuflavoside & {$[\mathrm{Xyl}(1 \rightarrow 2)][\mathrm{Rha}(1 \rightarrow 6)] \mathrm{Glc}$} & O-Glc & $\mathrm{OH}$ \\
\hline 104 & & $\mathrm{Xyl}(1 \rightarrow 2) \mathrm{Glc}$ & O-Glc & $\mathrm{OH}$ \\
\hline 106 & & {$[\mathrm{Xyl}(1 \rightarrow 2)][\mathrm{Glc}(1 \rightarrow 3)] \mathrm{Glc}$} & $\mathrm{OH}$ & $\mathrm{OH}$ \\
\hline 107 & & $\mathrm{Xyl}(1 \rightarrow 2)$ Glc $(1 \rightarrow 3) \mathrm{Glc}$ & $\mathrm{OH}$ & $\mathrm{OH}$ \\
\hline 108 & & {$[\mathrm{Xyl}(1 \rightarrow 2)][\mathrm{Glc}(1 \rightarrow 3)] \mathrm{Glc}$} & $\mathrm{OH}$ & $\mathrm{OCH}_{3}$ \\
\hline 109 & Quercetin 3-O-sambubioside & $\mathrm{Xyl}(1 \rightarrow 2) \mathrm{Glc}$ & $\mathrm{OH}$ & $\mathrm{OH}$ \\
\hline 113 & Quercitrin & Rha & $\mathrm{OH}$ & $\mathrm{OH}$ \\
\hline 114 & Quercetin 3-ara & Ara & $\mathrm{OH}$ & $\mathrm{OH}$ \\
\hline 115 & Distichin & Ara & $\mathrm{CH}_{3}$ & $\mathrm{OH}$ \\
\hline 116 & Kaempferal & $\mathrm{H}$ & $\mathrm{H}$ & $\mathrm{OH}$ \\
\hline 117 & & {$[\mathrm{Xyl}(1 \rightarrow 2)][\mathrm{Glc}(1 \rightarrow 6)] \mathrm{Glc}$} & $\mathrm{H}$ & $\mathrm{OH}$ \\
\hline 118 & & {$[\mathrm{Xyl}(1 \rightarrow 2)][\mathrm{Glc}(1 \rightarrow 3)] \mathrm{Glc}$} & $\mathrm{H}$ & $\mathrm{OH}$ \\
\hline 119 & & $\mathrm{Xyl}(1 \rightarrow 2)$ Glc $(1 \rightarrow 3)$ Glc & $\mathrm{H}$ & $\mathrm{OH}$ \\
\hline 120 & Leucoside & $\mathrm{Xyl}(1 \rightarrow 2) \mathrm{Glc}$ & $\mathrm{H}$ & $\mathrm{OH}$ \\
\hline 121 & Multiflorin B & Glc $(1 \rightarrow 4)$ Rha & $\mathrm{H}$ & $\mathrm{OH}$ \\
\hline
\end{tabular}

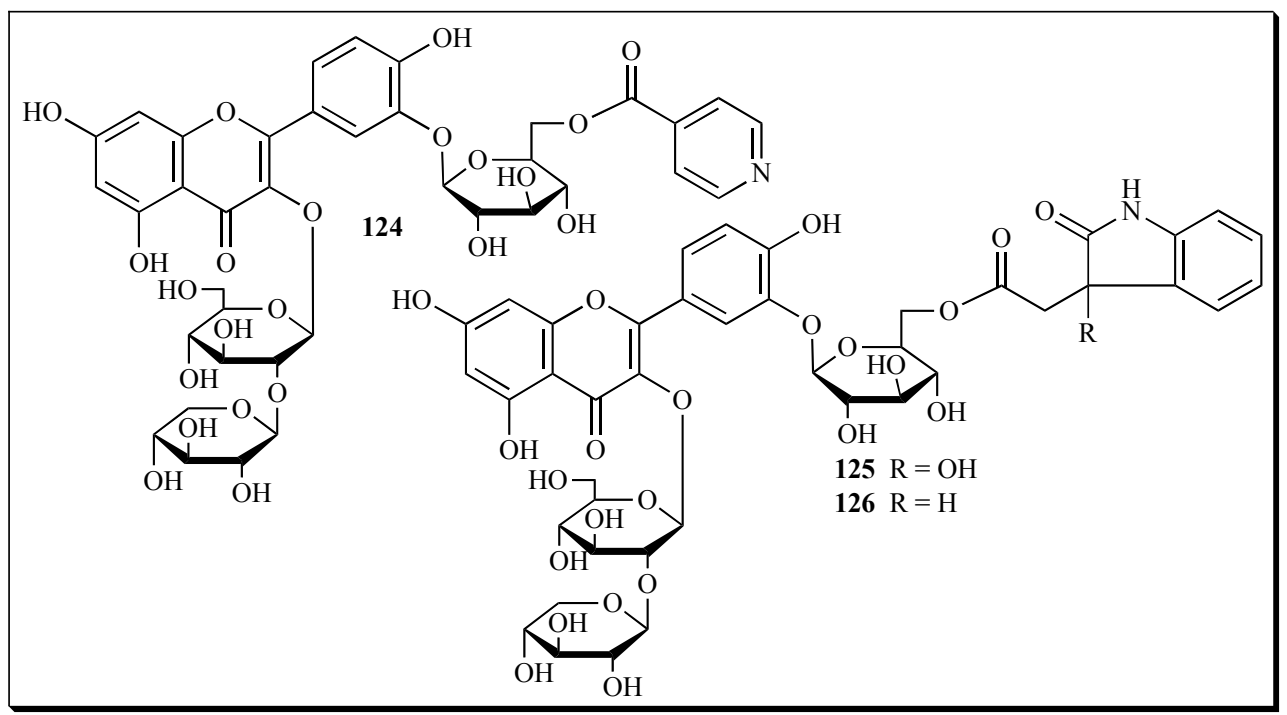



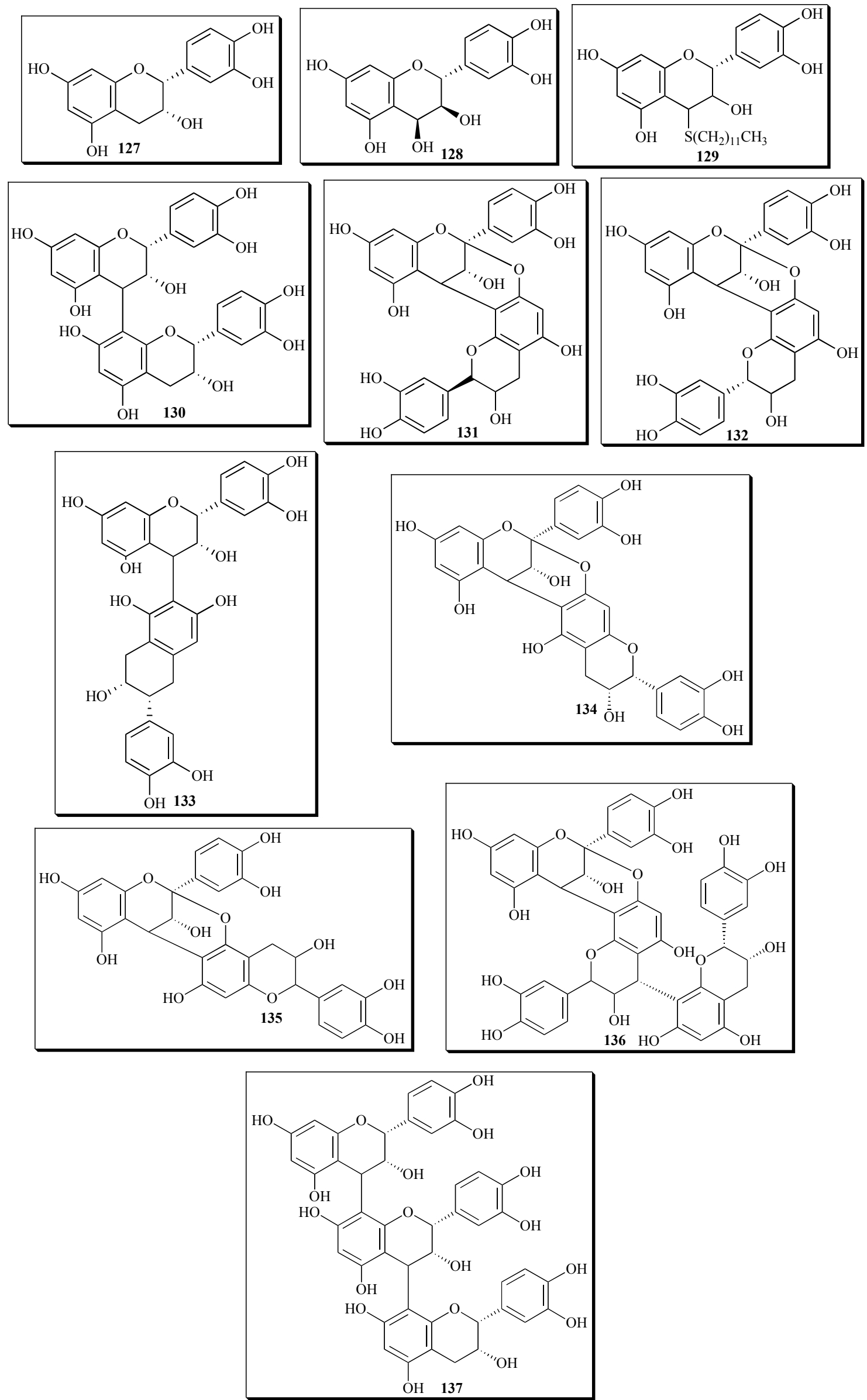

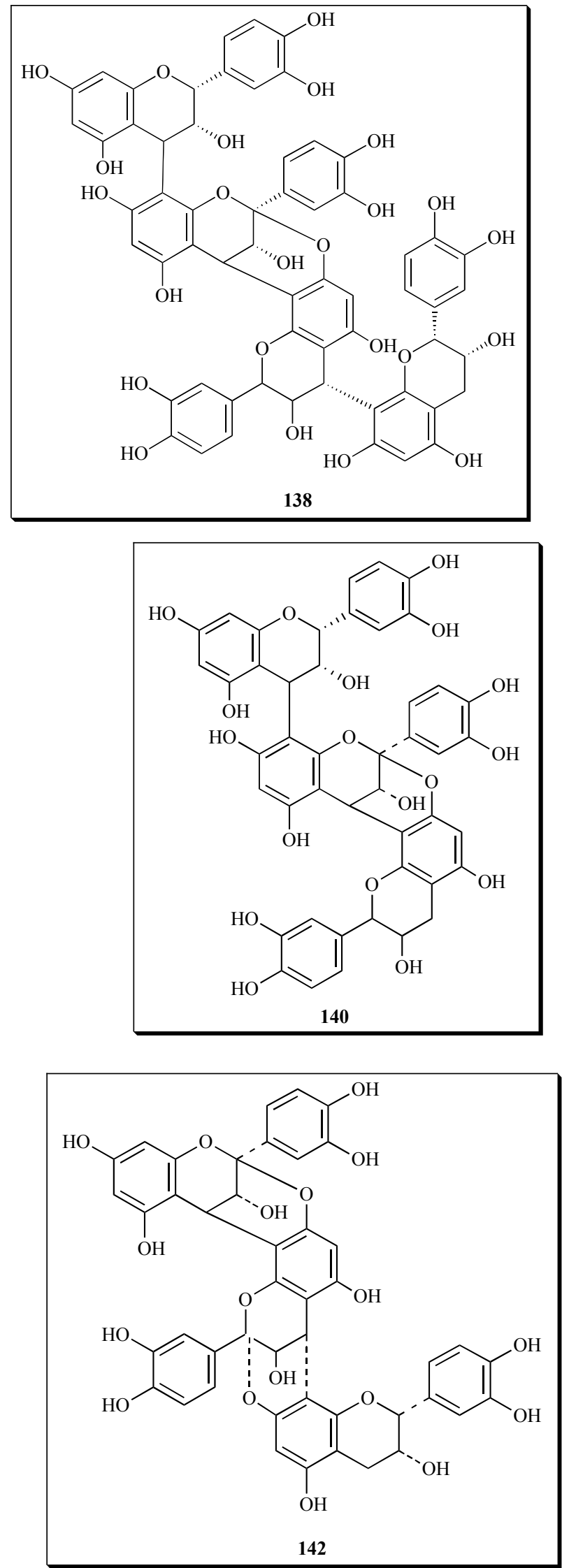
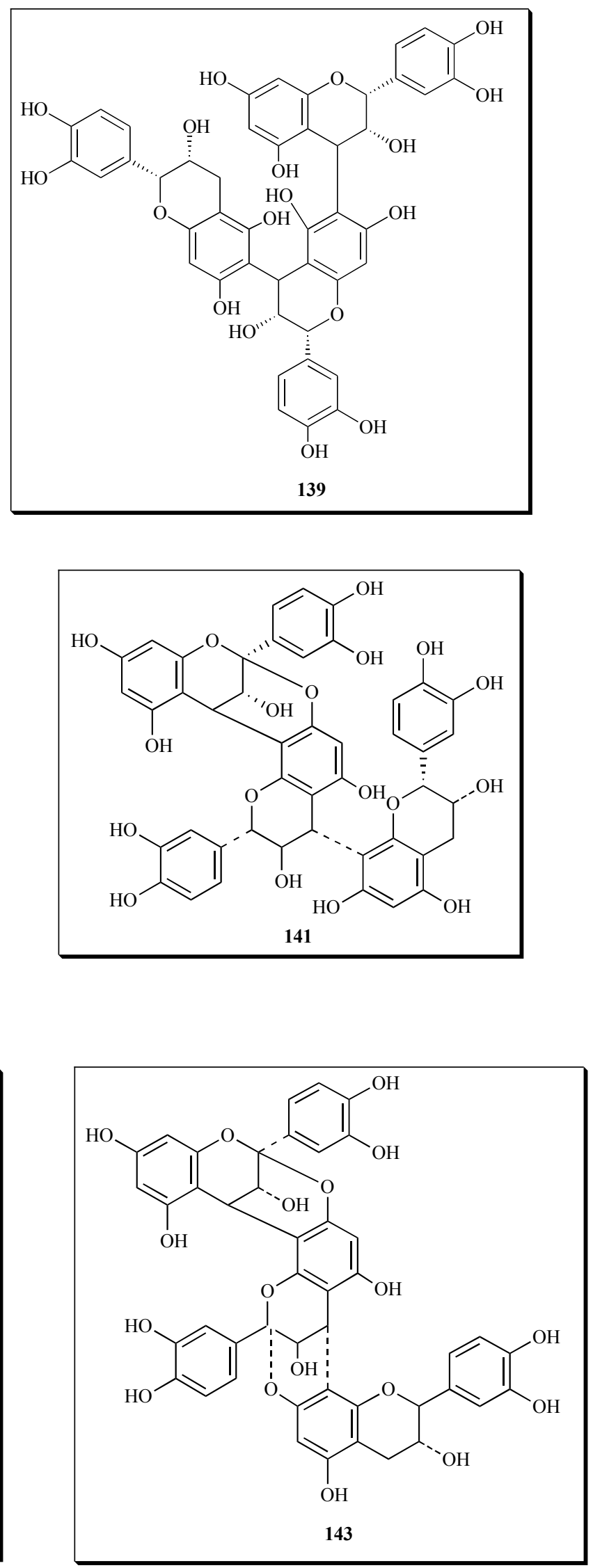

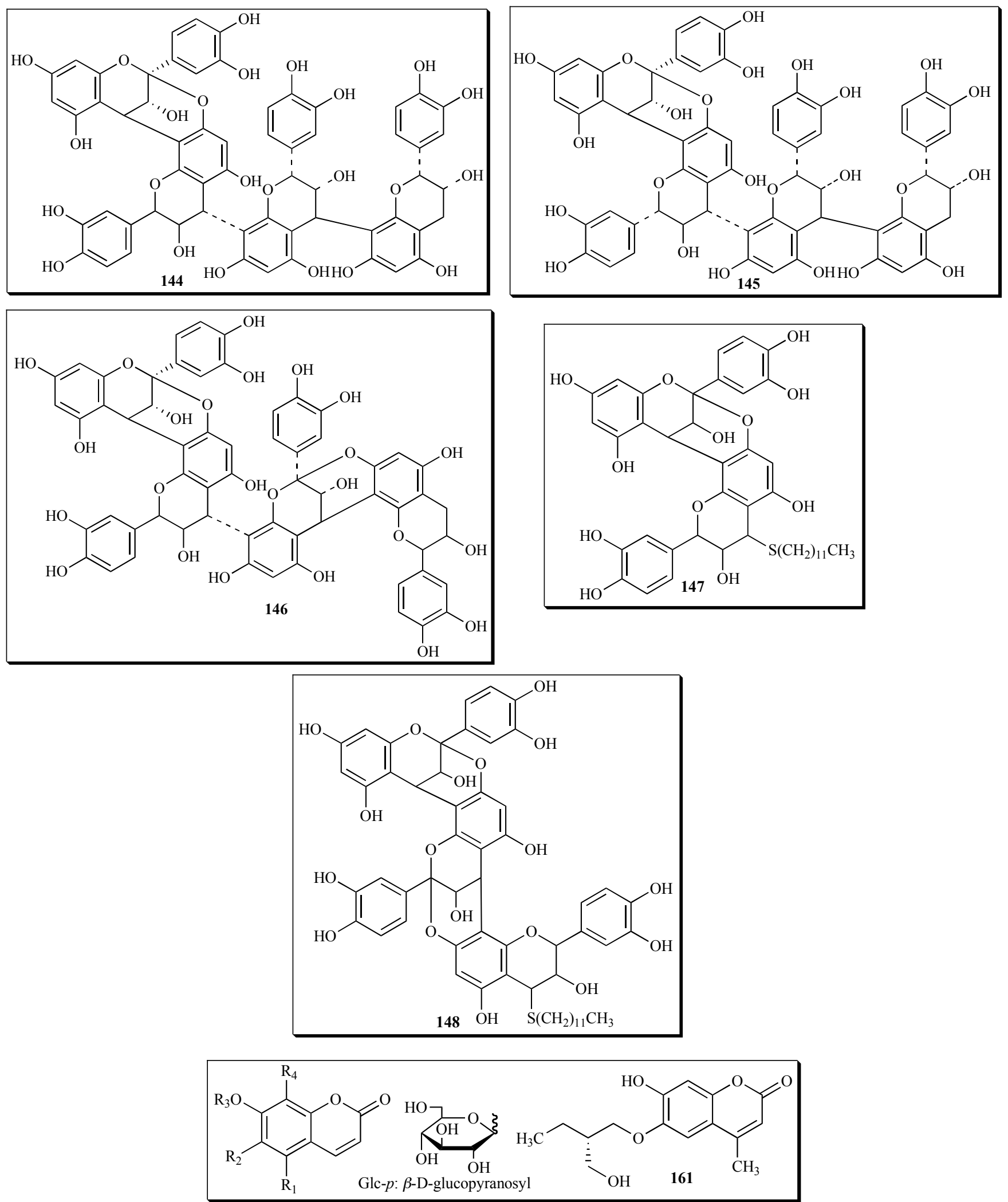

\begin{tabular}{|c|c|c|c|c|c|}
\hline No. & Name & $\mathbf{R}_{\mathbf{1}}$ & $\mathbf{R}_{\mathbf{2}}$ & $\mathbf{R}_{\mathbf{3}}$ & $\mathrm{H}$ \\
\hline \hline $\mathbf{1 4 9}$ & Umbelliferone & $\mathrm{H}$ & $\mathrm{H}$ & $\mathrm{H}$ & $\mathrm{H}$ \\
\hline $\mathbf{1 5 0}$ & Esculetin & $\mathrm{H}$ & $\mathrm{OH}$ & $\mathrm{H}$ & $\mathrm{OCH}$ \\
\hline $\mathbf{1 5 1}$ & Fraxetin & $\mathrm{H}$ & $\mathrm{OCH}_{3}$ & $\mathrm{OH}$ \\
\hline
\end{tabular}


Compounds 149-160 contd....

\begin{tabular}{|c|c|c|c|c|c|}
\hline 152 & Scopoletin & $\mathrm{H}$ & $\mathrm{OCH}_{3}$ & $\mathrm{OH}$ & $\mathrm{H}$ \\
\hline 154 & Skimin & $\mathrm{H}$ & $\mathrm{H}$ & Glc- $p$ & $\mathrm{H}$ \\
\hline 155 & Chikhorin & $\mathrm{H}$ & $\mathrm{OH}$ & Glc- $p$ & $\mathrm{H}$ \\
\hline 156 & Fraxin & $\mathrm{H}$ & $\mathrm{OCH}_{3}$ & $\mathrm{H}$ & $O$-Glc- $p$ \\
\hline 158 & Scopolin & $\mathrm{H}$ & $\mathrm{OCH}_{3}$ & Glc- $p$ & $\mathrm{H}$ \\
\hline 159 & Isoscopolin & $\mathrm{H}$ & Glc- $p$ & $\mathrm{OCH}_{3}$ & $\mathrm{H}$ \\
\hline 160 & 5-Methoxyscopolin & $\mathrm{OCH}_{3}$ & $\mathrm{OCH}_{3}$ & Glc- $p$ & $\mathrm{H}$ \\
\hline
\end{tabular}
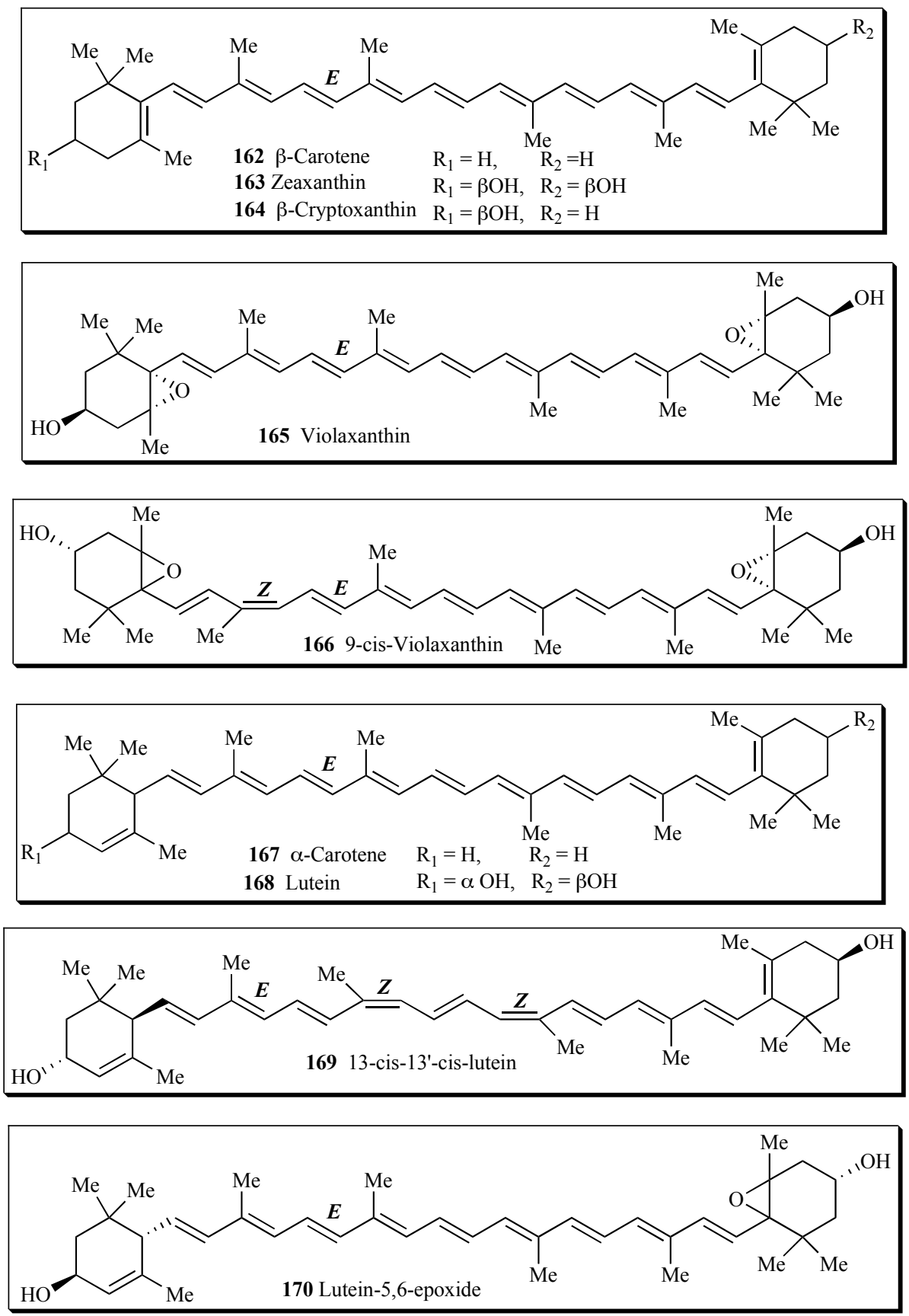

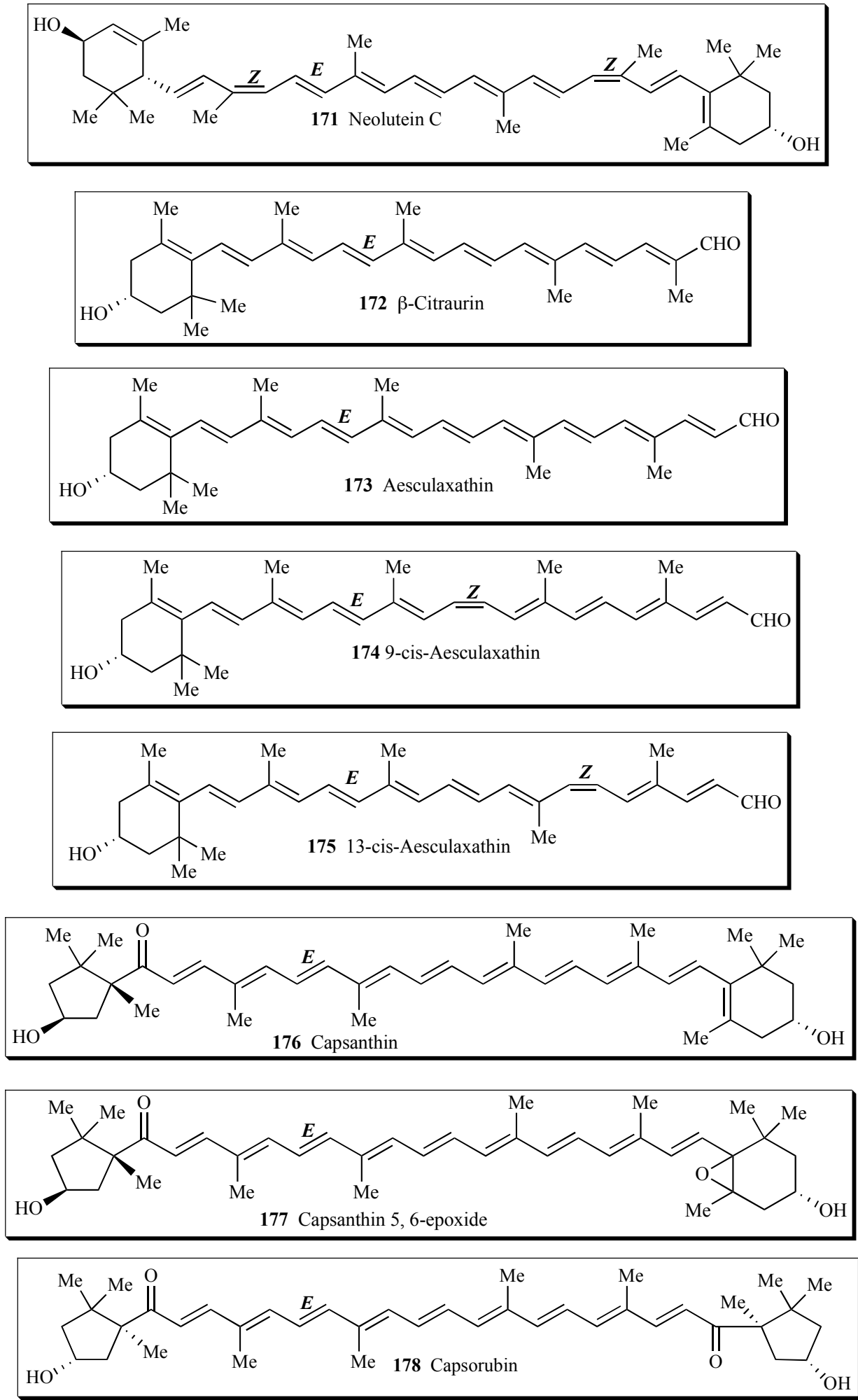

violaxanthin (166), lutein (168), 13-cis-13'-cis-lutein (169), lutein 5, 6-epoxide (170), neolutein C (171), $\beta$-citraurin (172), aesculaxanthin (173), 9-cis-aesculaxanthin (174), 13-cis-aesculaxanthin (175), 9'-cis-neoxanthin (179), 9-cis-9'-cis-neoxanthin (180), neochrome (181), and luteoxanthin (182) [75].

\section{Long Fatty Chain Compounds}

The seeds of Aesculus also contain a number of long fatty chain compounds. These compounds include lauric acid
(183), myristic acid (184), palmitic acid (185), stearic acid (189), arachic acid (190), and oleic acid (191) from $A$. hippocastanum and $A$. indica [76]; linoleic acid (192) from $A$. hippocastanum [70]; oleic acid (191), linoleic acid (192), and linolenic acid (193) from the seeds of A. turbinata [20]; heptadecanoic acid (186), methyl heptadecanoate (187), ethyl heptadecanoate (188), methyl octadec-(13Z)-enoate (194), ethyl octadec-(13Z)-enoate (195) [77], palmitone (197), n-hentriacontanol (198), and n-hentriacontane (199) 

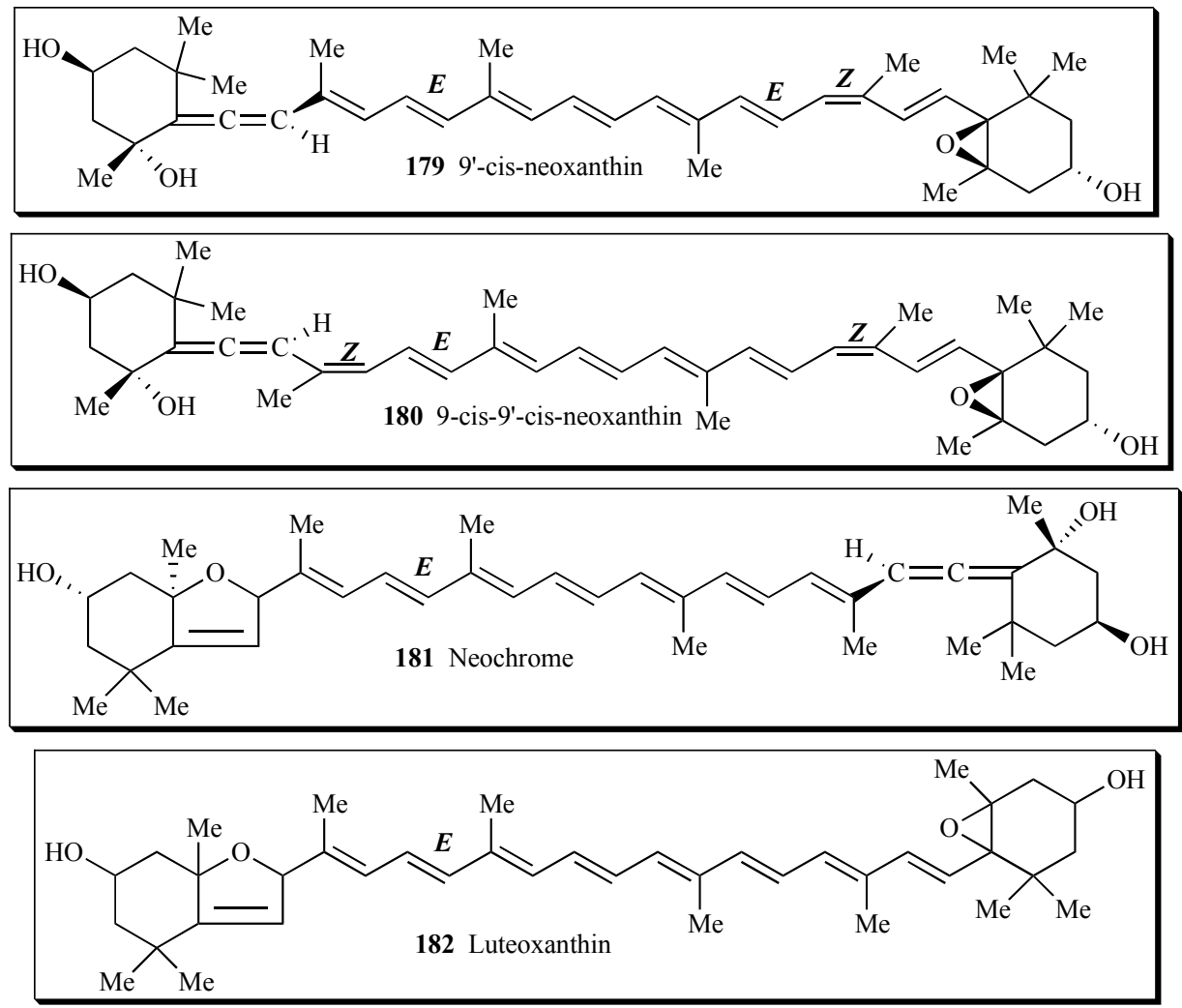

from A. indica [78]; and tianshic acid (196) from A. chinensis var. wilsonii [79].

\section{Other Compounds}

Some other classes of components were isolated and identified from some species of Aesculus. These compounds are ester of indole-3-acetic acid and myo-inositol (200), ester of indole-3-acetic acid and the disaccharide rutinose (201), three cyclopropane amino acids of cis- $\alpha$-(carboxycyclopropyl)-glycine (202), trans- $\alpha$-(carboxycyclopropyl)-glycine (203), and exo-3,4-methanoproline (204) from A. parviflora [80, 81]; 2-amino-4-methylhexanoic acid (205), 2-amino-4methylhex-4-enoic acid (206), $N$-(1-carboxy-3-methyl-3pentenyl-glutamine (207), $\alpha$-amino- $\beta$-methyl-2-methylenecyclopropanepropionic acid (208), 2-amino-6-hydroxy-4methylhex-4-enoic acid (209), and arbutin (210) from $A$. californica [68, 82]; and wilsonic acid (211), $N$-acetyl glutamic acid (212), and fumaric acid (213) from A. chinensis var. wilsonii $[79,83]$.

\section{BIOLOGICAL AND PHARMACOLOGICAL ACTIVI- TIES}

\section{Anti-inflammatory Activities}

The therapeutic benefits of HCSE and aescin for the treatment of chronic venous insufficiency, hemorrhoids, and postoperative edema are due to their significant antiinflammatory properties, which were demonstrated in animal models $[5,50,84,85]$. The anti-inflammatory activities of HCSE or aescin are related to the molecular mechanism of the agents, which include the improved entry of ions into channels [86] thus raising venous tension [87], the release of prostaglandin-F2a from veins [88], the release of inflamma- tory mediators by decreasing leukocyte activation and adhesiveness $[84,89]$, the antagonism to the pro-inflammatory 5HT receptors and histamine [90], and the decrease in the activity of tissue hyaluronidase [91].

Individual compounds isolated and identified from the genus Aesculus also showed anti-inflammatory properties. Escins Ia (21), Ib (22), IIa (23), and IIb (24) from A. hippocastanum prevented the increase of vascular permeability induced by both acetic acid in mice and histamine in acute inflammatory rats. Escins Ia, Ib, IIa, and IIb inhibited hind paw edema induced by carrageenin and scratching behavior in mice. However, desacylescins I (41) and II (42) without acyl groups had no effects in the animal model tested, which suggests that acyl groups in escins were essential for their activities [92]. Escins $\mathrm{Ia}, \mathrm{Ib}$, isoescins Ia (43), and $\mathrm{Ib}(\mathbf{4 4})$ isolated from the seeds of $A$. chinensis var. chinensis markedly inhibited dimethyl benzene induced inflammation in mice at a dose of $30 \mathrm{mg} / \mathrm{kg}$. The inhibitory effects of the four pure saponins were nearly equal to each other, but had more potent activity than a total saponin extract and dexamethasone, a commercially available anti-inflammatory drug [50]. Oleic acid (191), linoleic acid (192), and linolenic acid (193) from a hexane seed extract of $A$. turbinata showed an inhibition of the activity of cyclooxygenase (COX-1 and COX-2), the important target for anti-inflammatory drugs. Linolenic acid and linoleic acid had a high selectivity toward COX-2 [20].

\section{Anti-tumor Activities}

Recent studies in vivo and in vitro indicate that aescin $(\beta-$ escin) has significant antitumor activities. $\beta$-escin from $A$. hippocastanum inhibited chemically induced colon carcinogenesis in rats, and in vitro exhibited cytotoxicity at 30 

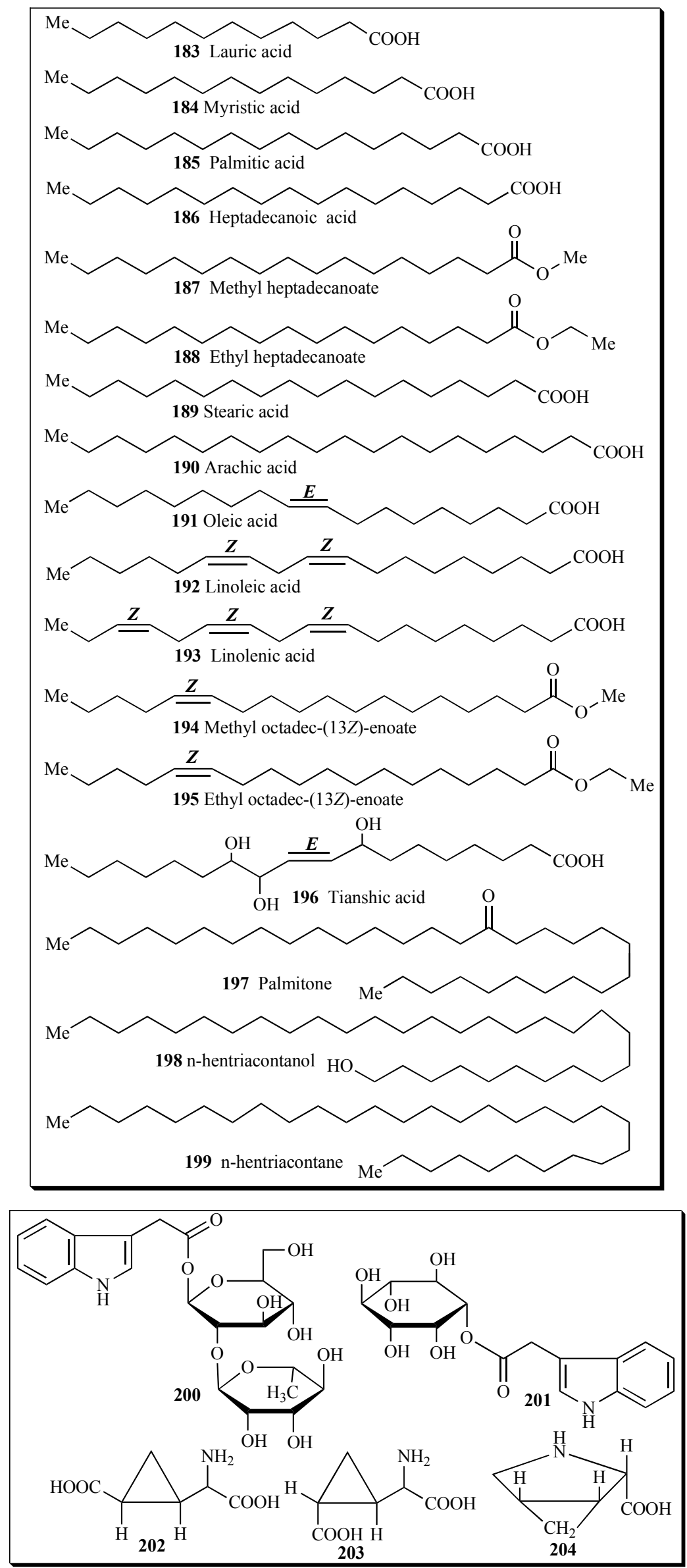


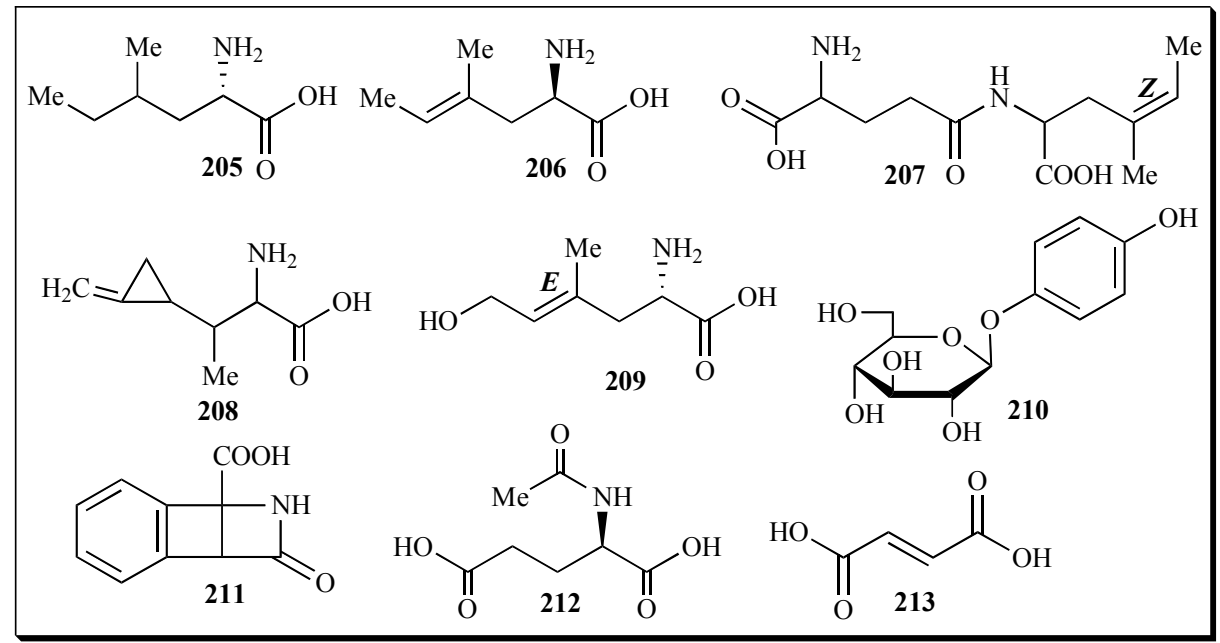

$\mu \mathrm{mol} / \mathrm{L}$ or above concentrations in colon cancer cell lines. $\beta$ Escin at $5 \mu \mathrm{mol} / \mathrm{L}$ also inhibited HT-29 colon cancer cell proliferation. $\beta$-escin induced cell cycle arrest at $\mathrm{G}_{1}-\mathrm{S}$ phase in part mediated by induction of $\mathrm{p} 21 \mathrm{WAF} 1 / \mathrm{CIP} 1$ and/or associated with reduced levels of $\mathrm{Cdk} 2$ and cyclins $\mathrm{A}$ and $\mathrm{E}$ complex; additionally, there was a lower phosphorylation of $\mathrm{Rb}$ [93].

$\beta$-escin isolated from the seeds of $A$. chinensis var. chinensis induced apoptosis and caused a significant inhibition of HL-60 human acute myeloid leukemia cell and K562huamn chronic myeloid leukemia cell proliferation in doseand time-dependent fasion. Morphological evidence of apoptosis, a significant increase of annexin V+ and PI- cells (early apoptotic) and apoptotic DNA fragmentation, were observed in K562 cells treated with $\beta$-escin. Flow cytometry analysis indicated that $\beta$-escin induced $\mathrm{G}_{1}-\mathrm{S}$ arrest and led to a significant accumulation of the sub- $\mathrm{G}_{1}$ population in HL60 and K562 cells [94, 95].

Aescin isolated from the seeds of A. chinensis var. wilsonii at a dose of $2.8 \mathrm{mg} / \mathrm{kg}$ had a rather high inhibition ratio $(43.5 \%)$ on mice H22 tumor growth in vivo. Aescin could induce significant concentration- and time-dependent inhibition of HepG (2) cell viability and induce cell cycle checkpoint arrest and caspase-independent cell death in HepG (2) cells [96].

An early investigation showed that two prosapogenins of 21-O-tigloyl-22- $O$-angeloyl- $\mathrm{R}_{1}$-barrigenol (10) and 21-Oangeloylbarringtogenol-C (18) from the acid hydrolysates of the HCSE of $A$. hippocastanum exhibited significant in vitro cytotoxicity with $\mathrm{ED}_{50}$ of $3.6 \mu \mathrm{g} / \mathrm{mL}$ and $3.0 \mu \mathrm{g} / \mathrm{mL}$, respectively, in the human nasopharyngeal carcinoma $9-\mathrm{KB}$ cell culture assay [27].

More recently, 28 individual saponins (72-99) from the fruits of $A$. pavia and six prosapogenins produced from these saponins were assayed in vitro for their cytotoxicity and inhibition of DNA topoisomerase I (TOP1) [61, 97]. Saponins 94, 96 and 98 with two acyl groups at C-21 and C-22 showed activity with $\mathrm{GI}_{50}$ of $0.175-8.71 \mu \mathrm{M}$ against most of 59 cell lines tested, which were from nine different human cancers including leukemia, non-small cell lung, colon, central nervous system (CNS), melanoma, ovarian, renal, prostate, and breast tumor cell lines. Aesculiosides IIc (79) and
IId (80) with only one acyl group at C-21 showed less activity while aesculiosides Ia-e (72-76) without acyl group showed no or weak activity [61]. Aesculiosides IIa-k (7787), IIIa-f (88-93), IVa (95), IVb (97), IVc (99), saponins 94, 96, 98 and six prosapogenins were also tested for their inhibition of DNA topoisomerase I (TOP1) and their activities against A549, PC-3, HL-60, PANC-1, and MRC cell lines. Most of the tested saponins and prosapogenins with acyl groups showed cytotoxic activity with different $\mathrm{GI}_{50}$ value. Sixteen cytotoxic aesculiosides 77-80 and 88-99 inhibited TOP1 catalytic activity by interacting directly with the free enzyme and preventing the formation of the DNA-TOP1 complex. Interestingly, six prosapogenins, including 21-Oangeloylproaescigin (13), 21,22-O-diangeloylprotoaescigenin (16), 21,22-O-diangeloylbarringtogenol-C (20), 21-O-angelyol-22-O-2-methylbutanoyl- $\mathrm{R}_{1}$-barrigenol, 21- $O$-angelyol22-O-2-methylbutanoylprotoaescigenin, and 21- $\mathrm{O}$-angelyol22-O-2-methylbutanoylbarringtogenol-C prepared from the acid hydrolysates of saponins 78, 96, 98, 95, 97, and 99, respectively, showed no TOP1 inhibitory activity, but had stronger cytotoxicity when compared to the related saponins [97].

\section{Antiviral and Antifungal Activities}

Isoescins Ia (43) and Ib (44) and escins Ia (21), Ib (22), IVc (28), IVd (29), IVe (30), and IVf (31) isolated from the seeds of $A$. chinensis var. chinensis showed activity against HIV-1 protease. Escins Ia (21) and Ib (22) inhibited the enzyme's activity by $86.1 \pm 0.2 \%$ at $100 \mu \mathrm{M}$ with $\mathrm{IC}_{50}$ values of 35 and $50 \mu \mathrm{M}$, respectively, while saponins 28-31, 43, and 44 showed weaker antiviral activity [47].

Three flavonol glycosides of aescuflavoside (103), aescuflavoside A (105), and leucoside (120) from A. chinensis var. chinensis showed significant antiviral activities against respiratory syncytial virus with $\mathrm{IC}_{50}$ values of $4.5,6.7$, and 4.1 $\mu \mathrm{g} / \mathrm{mL}$, and selective index values of $15.8,32$, and 63.8 , respectively. Astragalin (122) demonstrated significant antiviral activity against influenza virus type $\mathrm{A}$ with an $\mathrm{IC}_{50}$ of $24.5 \mu \mathrm{g} / \mathrm{mL}$ and a selective index of 16.0 [66].

Pavietin (161), a new prenylated coumarin, isolated from the leaves of a genotype of A. pavia, showed antifungal activity. In a preliminary antifungal screening by filter disk 
method, pavietin $(15 \mathrm{mg} /$ dish) possessed significant activity against an Aesculus-specific fungal parasite, Guignardia aesculi, and weaker activity against the generalist polyphagous Pythium ultimum and the Aesculus nonpathogenic Fusarium basilici. More detailed antifungal screening by adding pavietin to mycelial growth medium of different fungal pathogens showed that pavietin exhibits appreciable antimicrobial properties against several pathogens including Alternaria alternata, A. dianthi, Aspergillus niger, Botrytis cinerea, Cladosporium fulvum, Fusarium oxysporum dianthi, Guignardia aesculi, Penicillium expansum, Polyporus marginatus, Rhizopus stolonifer, and Trichoderma viride [67].

\section{Antiangiogenic Activities (Vascular Protection)}

$\beta$-escin sodium inhibited angiogenesis in chick chorioallantoic membrane [98] and in aortic disk assay [99]. Further study indicated that $\beta$-escin sodium $(10,20$, and $40 \mu \mathrm{g} / \mathrm{mL})$ dose-dependently inhibited endothelial cells (ECs) proliferation in human umbilical vein endothelial cells and ECV304 cells. $\beta$-escin sodium also induced ECs apoptosis at 40 $\mu \mathrm{g} / \mathrm{mL}$ and suppressed ECs migration and cell motility. Western blot results suggest that $\beta$-escin sodium acts on ECs possibly by increasing expression of thrombospondin-1, decreasing expression of PKC- $\alpha$ and activation of $\mathrm{p} 44 / 42 \mathrm{mi}-$ togen-activated protein (MAP) kinase and p38 mitogenactivated protein kinase (p38 MAPK) [100].

Aescin from A. hippocastanum was found to improve endothelial dysfunction in rat aortic rings subjected to oxidative stress generated by pyrogallol and to induce contraction in these preparations. These apparently contradicting effects could be due to the well-known ability of escin to enhance cellular permeability to calcium which, on one hand, would increase endothelial nitric-oxide synthase (eNOS) activity and nitric oxide production and would lead to vascular smooth muscle contraction. Endothelial protection could contribute to the therapeutic usefulness of escin, while arterial vasoconstriction could represent a limiting side effect in susceptible patients [101].

When HUVECs (human vascular endothelial cells) were exposed to $\mathrm{CoCl}_{2}$ as an in vitro model of hypoxia, aescin from A. hippocastanum, in a dose-dependent fashion (0.1-1.0 $\mu \mathrm{M})$, prevented the action of $\mathrm{CoCl}_{2}$ on the vascular cell adhesion molecule (VCAM-1) and platelet endothelial cell adhesion molecule (PECAM-1) and preserved endothelial cell morphology. In an in vitro model of inflammation induced by Escherichia coli lipopolysaccaride (LPS), aescin reduced IL-6 release from LPS-activated vascular endothelium [102].

HCSE from A. hippocastanum dose-dependently contracted both bovine mesenteric veins and arteries, with veins being the more sensitive. Contraction of both veins and arteries was significantly inhibited by the 5-HT(2A) receptor antagonist ketanserin. HCSE also significantly reduced ADPinduced human platelet aggregation. These findings may, at least partly, account for the mechanism of action of HCSE in the treatment of chronic venous insufficiency [103].

\section{Anti-obesity Effects}

Escins Ia (21), Ib (22), IIa (23), IIb (24), deacetylescins Ia (37), Ib (38), IIa (39), IIb (40), and desacylescins I (41) and II (42) had inhibitory effects on the elevation of blood glucose levels by means of the oral glucose tolerance test in mice. Escins (21-24) with two acyl groups had stronger activity than deacetylescins (37-40) with only one acyl group and desacylescins $(\mathbf{4 1}, \mathbf{4 2})$ without acyl group $[38,39,43]$. These compounds also exhibited the activity of pancreatic lipase with very different $\mathrm{IC}_{50}$ values. Escins (21-24) had low $\mathrm{IC}_{50}$ values of $14-61 \mu \mathrm{g} / \mathrm{mL}$, while deacetylescins Ia and IIa had very high $\mathrm{IC}_{50}$ values of 345 , and $>400 \mu \mathrm{g} / \mathrm{mL}$, respectively [43]. Escins (21-24) with two acyl groups at C-21 and C-22 showed potent inhibitory activity on ethanol absorption in the dose of $50-100 \mathrm{mg} / \mathrm{kg}[38,39]$. An analysis comparing the structure and activity suggested that the acyl groups at $\mathrm{C}-21$ and $\mathrm{C}-22$ in these saponins were important for their activities.

Testing by using 4-methylumbelliferyl oleate as a substrate, escins (21-24), deacetylescins (37-40), and desacylescins $(\mathbf{4 1}, \mathbf{4 2})$ isolated from the natural and edible seeds of A. turbinata exhibited inhibitory effect on lipase activity. The potency was in the order of escins $>$ desacylescins $>$ deacetylescins. Escins Ib and IIb as well as deacetylescins Ib and IIb with the angeloyl moiety were more potent than the corresponding Ia and IIa series with the tigloyl moiety. Saponin fractions from natural seeds (SFNS) and edible seeds (SFES) of A. turbinata effectively inhibited fat digestion in an in vivo anti-obesity experiment in mice fed highfat diets. SFNS $(0.1 \%$ or $0.5 \%)$ and SFES $(0.5 \%)$ both significantly attenuated the elevation in body weight, the mass of peritoneal adipose tissues, and plasma triacylglycerol, which was accompanied by higher contents of undigested fats in feces without changes in food intake [104]. Escins Ib and IIa also inhibited pancreatic lipase activity with dosedependence $(0-0.5 \mathrm{mg} / \mathrm{mL})$ in an in vitro assay system using triolein emulsified with lecithin [105].

In addition, assamicins I $(67,100 \mu \mathrm{g} / \mathrm{mL})$ and II $(68,25$ $\mu \mathrm{g} / \mathrm{mL}$ ) almost completely inhibited release of free fatty acids from epinephrine-treated rat adipocytes. Both compounds enhanced glucose uptake into 3T3-L1 adipocytes as insulin does. When the cells were incubated in a medium containing $[3 \mathrm{H}]$-2-deoxyglucose, the uptake of the radioisotope into the cells was enhanced 2.5- and 3.5-fold by addition of assamicins I and II, respectively, at the concentration of $25 \mu \mathrm{g} / \mathrm{mL}$. Assamicin II showed stronger activity than assamicin I in both assay systems tested [57].

\section{Antioxidant and Antigenotoxic Activities}

HCSE from the seeds of A. turbinata dose-dependently inhibited the autooxidation of linoleic acid $\left(\mathrm{IC}_{50}\right.$ of 0.2 $\mathrm{mg} / \mathrm{mL}$ ) and the inhibition was almost complete at a concentration of $1 \mathrm{mg} / \mathrm{mL}$. The HCSE scavenged DPPH radicals and superoxide anions with $\mathrm{IC}_{50}$ of 0.65 and $0.21 \mathrm{mg} / \mathrm{mL}$, respectively. The polyphenols $(21 \mathrm{mg} / \mathrm{g})$ in the HCSE were the main active compounds [106]. This HCSE also inhibited the genotoxicities induced by furylfuramide, $\mathrm{N}$-methyl- $\mathrm{N}$ nitrosourea, methyl methanesulfonate, mitomycin $\mathrm{C}$, 2aminoanthracene and aflatoxin $\mathrm{B}_{1}$ at a concentration of 1 $\mathrm{mg} / \mathrm{mL}$ or more [106].

Aescin from the seeds of $A$. hippocastanum increased the antioxidative defense system of the body and prevented high fat diet (HFD)-induced lipid peroxidation in male mice fed either standard pellet diet (SPD) or HFD at $100 \mathrm{mg} / \mathrm{kg}$ doses 
daily for 5 weeks. Aescin mixture prohibited the adverse effects of oxidative stress and showed a protective effect on the liver architecture both in SPD and HFD consumed male mice. Combined administration of high-fat diet with escin mixture significantly increased blood and liver reduced glutathione GSH levels in mice and decreased the level of malondialdehyde in blood, liver, kidney, heart, the level of liver superoxide dismutase, and the catalase activity [107].

Three docyl sulfide derivatives of (-)-epicatechin (129) and proanthocyanidins $(\mathbf{1 4 7}, \mathbf{1 4 8})$ isolated from the seeds of A. turbinata showed potent antioxidative activity by assaying with DPPH (1,1-diphenyl-2-picrylhydrazyl). Compounds 147 and 148 exhibited similar antioxidative activities with $\mathrm{IC}_{50}$ of $2.4-2.6 \mu \mathrm{g} / \mathrm{mL}$. Their inhibitory actions were slightly more potent than that of the monomer of $(-)$-epicatechin or $(+)$-catechin [19].

\section{CONCLUSIONS}

The genus Aesculus has 12 species, but only A. hippocastanum and $A$. chinensis var. chinensis, two Eurasian species, are officially recognized sources of herbal products in traditional medicine. HCSE or aescin from A. hippocastanum has shown satisfactory evidence for clinically significant activity in chronic venous insufficiency, hemorrhoids, and postoperative oedema, largely due to its anti-inflammatory properties, which were well demonstrated by in vitro and in vivo assay. However, the mechanism of action of the Chinese horse chestnut is poorly understood and further investigation is necessary.

Although other constituents may have some bioactivity, the polyhydroxylated triterpenoid glycosides (saponins) in Aesculus extract are considered to be the major active principles. To date, the saponins from the seeds of six species including A. hippocastanum (AH), A. chinensis var. chinensis (ACC), A. chinensis var. wilsonii (ACW), A. turbinata (AT), A. assamica (AA), and A. pavia (AP) have been well documented. Very interestingly, the saponins from four Eurasian species (AH, ACC, ACW, and AT) have very similar structures but are different from the novel cytotoxic saponins from an eastern North American species A. pavia. This chemical difference suggests a chemotaxonomic significance between the two groups $[13,61]$. More studies of the saponins from the seeds of other North American species are necessary to further confirm the chemotaxonomic value of these novel cytotoxic saponins. Detailed investigations on the saponins from the seeds of other Aesculus species, which have not been conducted phytochemically, are also needed to fully understand the chemical profile of the genus Aesculus. These studies, which are now being conducted at Stephen F. Austin State University, may not only identify more bioactive saponins but could also provide chemotaxonomic data for the genus Aesculus and better understanding of its evolution.

The biological and pharmacological activities of HCSE, aescin, and individual components from the genus Aesculus have received much interest in recent years. Accumulated studies indicate that HCSE, aescin, and individual compounds have anti-inflammatory, antitumor, antiviral, antifungal, antiangiogenic (vascular protection), anti-obesity antioxidative, and antigenotoxic properties. One of the most interesting activities is the antitumor property of some novel saponins discovered recently from A. pavia. This type of novel saponins has showed potent cytotoxicity and inhibition of TOP1 by in vitro assays [61, 97, 108]. Further animal studies are required to evaluate the potential for the treatment of cancer as anticancer agents.

\section{ACKNOWLEDGEMENTS}

This work was partially funded by the USDA Grant 2008-38928-19308.

\begin{tabular}{|c|c|c|}
\hline \multicolumn{3}{|c|}{ ABBREVIATIONS } \\
\hline A549 & $=$ & $\begin{array}{l}\text { Human lung adenocarcinoma epithelial } \\
\text { cell line }\end{array}$ \\
\hline Ac & $=$ & Acetyl \\
\hline Ang & $=$ & Angeloyl \\
\hline CNS & $=$ & Central nervous system \\
\hline $\mathrm{COX}$ & $=$ & Cyclooxygenase \\
\hline DPPH & $=$ & 1,1-diphenyl-2-picrylhydrazyl \\
\hline $\mathrm{EC}$ & $=$ & Inhibited endothelial cell \\
\hline eNOS & $=$ & Endothelial nitric-oxide synthase \\
\hline HCSE & $=$ & Horse chestnut seed extract \\
\hline HFD & $=$ & High fat diet \\
\hline HL-60 & $=$ & $\begin{array}{l}\text { Human promyelocytic leukemia cell } \\
\text { line }\end{array}$ \\
\hline HUVEC & $=$ & Human vascular endothelial cell \\
\hline LPS & $=$ & Lipopolysaccaride \\
\hline MAP & $=$ & Mitogen-activated protein \\
\hline MB & $=$ & 2-methylbutanoyl \\
\hline MP & $=$ & 2-methylpropanoyl \\
\hline MARC-5 & $=$ & Human normal lung cell line \\
\hline p38 MAPK & $=$ & p38 mitogen-activated protein kinase \\
\hline PANC-1 & $=$ & $\begin{array}{l}\text { Human pancreatic carcinoma, epithe- } \\
\text { lial-like cell line }\end{array}$ \\
\hline PECAM-1 & $=$ & $\begin{array}{l}\text { Platelet endothelial cell adhesion mole- } \\
\text { cule }\end{array}$ \\
\hline SFES & $=$ & Saponin fractions from edible seed \\
\hline SFNS & $=$ & Saponin fractions from natural seed \\
\hline SPD & $=$ & Standard pellet diet \\
\hline STE & $=$ & Standardized therapeutic extract \\
\hline Tig & $=$ & Tigloyl \\
\hline TOP1 & $=$ & DNA topoisomerase I \\
\hline VCAM-1 & $=$ & Vascular cell adhesion molecule \\
\hline
\end{tabular}

\section{REFERENCES}

[1] Hardin, J. W. A revision of the American Hippocastanaceae. Brittonia, 1957, 9, 145-95.

[2] Hardin, J. W. Studies in the hippocastanaceae, V. species of the old world. Brittonia, 1960, 12, 26-38.

[3] Xia, N.H.; Thurland, N.J.; Gadek, P.A. Hippocastanaceae. In Flora of China, Vol. 12, pp. 1-4. 'eFloras (2010). Published on the Internet http://www.efloras.org', Missouri Botanical Garden, St. Louis, 
MO \& Harvard University Herbaria, Cambridge, MA [accessed June 30, 2010]

[4] Xiang, Q. Y.; Crawford, D. J.; Wolfe, A. D.; Tang, Y. C.; DePamphilis, C. W. Origin and biogeography of Aesculus L. (Hippcastanaceae): a molecular phylogenetic perspective. Evolution, 1998, 52(4), 988-997.

[5] Sirtori, C.R. Aescin: pharmacology, pharmacokinetics and therapeutic profile. Pharmacol. Res., 2001, 44, 183-93.

[6] Bisset, N. G. Herbal Drugs and Phytopharmaceuticals. Medpharm Scientific Publishers, CRC Press: Stuttgart, Germany, 1994; pp. 268-272.

[7] Bielanski, T. E.; Piotrowski, Z. H. Horse-chestnut seed extract for chronic venous insufficiency. J. Fam. Pract., 1999, 48, 171-172.

[8] Kahn, S. R. Review: horse chestnut seed extract is effective for symptoms of chronic venous insufficiency. ACP J. Club, 2006, 145(1), 20.

[9] Persson, I. A. L.; Persson, K. Horse chestnut (Aesculus hippocastanum L.). Recent Prog. Med. Plants, 2010, 28, 159-171.

[10] Jiangsu New Medical College. Zhong Yao Da Ci Dian. Shanghai People's Public Health Press: Shanghai, P. R. China, 1977; pp. 1961.

[11] Institute of Materia Medica, Chinese Academy of Medical Sciences. Zhong Yao Zhi. People's Health Press: Beijing, P.R. China, 1984; vol. 4, pp. 555.

[12] Koch, K. Monographie du genre Aesculus (translated from German by A. de Borre). Belg. Hortic., 1857, 7, 309-319.

[13] Forest, F.; Drouin, J. N.; Charest, R. C.; Brouillet, L.; Bruneau, A. F. A morphological phylogenetic analysis of Aesculus L. and Billia Peyr. (Sapindaceae). Can. J. Bot., 2001, 79, 154-169.

[14] Turland, N.J.; Xia, N.H. A new combination in Chinese Aesculus (Hippocastanaceae). Novon, 2005, 15, 488-489.

[15] Umadevi, I.; Daniel, M. Chemosystematics of the sapindaceae. Feddes Repert., 1991, 102, 607-612.

[16] Zhang, Z. Z.; Li, S. Y.; Zhang, S. M.; Gorenstein, D. Triterpenoid saponins from the fruits of Aesculus pavia. Phytochemistry, 2006, 67(8), 784-794.

[17] Chanon, A. M. Studies on the reproductive capacity of Aesculus parviflora and A. pavia: Opportunities for their improvement through interspecific hybridization. The Ohio State University Thesis, 2005, 264 pp.

[18] Bombardelli, E.; Morazzoni, P.; Griffini, A. Aesculus hippocastanum L. Fitoterapia, 1996, 67(6), 483-511.

[19] Ogawa, S.; Kimura, H.; Niimi, A.; Katsube, T.; Jisaka, M.; Yokota, $\mathrm{K}$. Fractionation and structural characterization of polyphenolic antioxidants from seed shells of Japanese horse chestnut (Aesculus turbinata Blume). J. Agric. Food Chem., 2008, 56(24), 1204612051

[20] Sato, I.; Kofujita, H.; Tsuda, S. Identification of COX inhibitors in the hexane extract of Japanese horse chestnut (Aesculus turbinata) seeds. J. Vet. Med. Sci., 2007, 69(7), 709-712.

[21] Parmar, C.; Kaushal, M. K. Aesculus indica. In Wild Fruits, Kalyani Publishers: New Delhi, India, 1982; pp. 6-9.

[22] Collingwood, G..H.; Brush, W. Knowing your trees. American Forestry Assoc., Washington, D.C. 1964.

[23] Hamel, P.B.; Chiltoskey, M.U. Cherokee plants and their uses: A 400-year history. Herald Publishing, Sylva, NC, 1975.

[24] Bocek, B.R. Ethnobotany of Costanoan Indians, California, based on collections by John P. Harrington. Econ. Bot., 1984, 38(2), 240255.

[25] Cainelli, G.; Melera, A.; Arigoni, D.; Jeger, O. Zur kenntnis der triterpene. 194. Konstitution des Äscigenins. Helv. Chim. Acta, 1957, 40(7), 2390-2409.

[26] Wulff, G.; Tschesche, R. Uber triterpene-XXVI Uber die struktur der rosskastaniensaponine (aescin) und die aglykone verwandter glykoside. Tetrahedron, 1969, 25, 415-436.

[27] Konoshima, T.; Lee, K. H. Antitumor agents, 82. Cytotoxic sapogenols from Aesculus hippocastanum. J. Nat. Prod., 1986, 49(4), 650-656.

[28] Kuhn, R.; Low, I. Uber die protoascigenin aus ascin. Tetrahedron, 1966, 22, 1899-906.

[29] Sati, O. P.; Rana, U. Triterpenoids of Aesculus indica. Die Pharmazie, 1987, 42(2), 141

[30] Schrutka-Rechtenstamm, R.; Robien, W.; Jurenitsch, J. Structure of the sapogenins of seeds from Aesculus pavia L. Pharmazie, 1988, $43,208-210$
[31] Aurada, E.; Jurenitsch, J.; Kubelka, W. Structure of TriterpeneSapogenins of Aesculus glabra. Planta Med., 1984, 50(5), 391-394.

[32] Liu, H. W.; Yao, X. S.; Wang, N. L.; Cai, G. P. Chemical components of Aesculus assamica. Zhongguo Tianran Yaowu, 2005, 3(6), 350-353.

[33] Prakash, D.; Misra, G.; Nigam, S. K. Chemistry of Aesculus punduana Wall. (A. assamica Griff.) seeds. Fitoterapia, 1980, 51(6), 285-287.

[34] Yang, L.; Zhao, X. A.; Ma, L. B. Studies on sapogenins of Aesculus wilsonii Rehd. Zhongguo Zhongyao Zazhi, 1996, $21(10), 617-$ 618.

[35] Hoppe, W.; Gieren, A.; Brodherr, T. R.; Wulff. G. Structure of the principal aglycone of horse chestnut saponin, Angew Chem. Int. Ed. Engl., 1968, 7, 547-548.

[36] Pietta, P.; Mauri, P.; Maffei Faccino, R.; Carini, M. Highperformance liquid chromatographic analysis of $\beta$-escin. J. Chromatograph., 1989, 478, 259-263.

[37] Facino, R. M.; Carini, M.; Moneti, G.; Arlandini, E.; Pietta, P.; Mauri, P. Mass spectrometric characterization of horse chestnut saponins (Escin). Org. Mass. Spectrom., 1991, 26, 989.

[38] Yoshikawa, M.; Harada, E.; Murakami, T.; Matsuda, H.; Wariishi, N.; Yamahara, J.; Murakami, N.; Kitagawa, I. Escins Ia, Ib, IIa, IIb, and IIIa, bioactive triterpene oligoglycosides from the seeds of Aesculus hippocastanum L.: their inhibitory effects on ethanol absorption and hypoglycemic activity on glucose tolerance test. Chem. Pharm. Bull., 1994, 42(6), 1357-1359.

[39] Yoshikawa, M.; Murakami, T.; Matsuda, H.; Yamahara, J.; Murakami, N.; Kitagawa, I. Bioactive saponins and glycosides. III. Horse chestnut. (1): the structures, inhibitory effects on ethanol absorption, and hypoglycemic activity of escins $\mathrm{Ia}, \mathrm{Ib}, \mathrm{IIa}$, IIb, and IIIa from the seeds of Aesculus hippocastanum L. Chem. Pharm. Bull., 1996, 44(8), 1454-1464.

[40] Yoshikawa, M.; Murakami, T.; Yamahara, J.; Matsuda, H. Bioactive saponins and glycosides. XII. Horse chesnut. (2): Structures of escins IIIb, IV, V, and VI and Isoescins $\mathrm{Ia}, \mathrm{Ib}$, and $\mathrm{V}$, acylated polyhydroxyoleanene triterpene oligoglycosides, from the seeds of horse chestnut tree (Aesculus hippocastanum L., Hippocastanaceae. Chem. Pharm. Bull., 1998, 46(11), 1764-1769.

[41] Zhao, J.; Yang, X. W. Chemical constituents of Japanese buckeye seed (Aesculus turbinata) I. Isolation and identification of escins Ia and Ib. Zhongcaoyao, 1999, 30(5), 327-332.

[42] Kimura, H.; Watanabe, A.; Jisaka, M.; Yamamoto, T.; Kimura, Y.; Katsube, T.; Yokota, K. Chemical structures of saponins from seeds of edible horse chestnuts (Aesculus turbinata) after treatment with wooden ashes and their hypoglycemic activity. Nippon Shokuhin Kagaku Kogaku Kaishi, 2004, 51(12), 672-679.

[43] Kimura, H.; Ogawa, S.; Jisaka, M.; Kimura, Y.; Katsube, T.; Yokota, $\mathrm{K}$. Identification of novel saponins from edible seeds of Japanese horse chestnut (Aesculus turbinata Blume) after treatment with wooden ashes and their nutraceutical activity. J. Pharm. Biomed. Anal., 2006, 41(5), 1657-1665.

[44] Yang, X. W.; Zhao, J.; Hatori, Y. Chemical constituents of Japanese buckeye seed (Aesculus turbinata) Part II. Isolation and identification of escins IVc and isoescins Ia, Ib. Zhongcaoyao, 2000 $31(9), 648-651$.

[45] Yang, X. W.; Zhao, J.; Hattori, M. Three new triterpenoid saponins from the seeds of Aesculus turbinata. J. Asian Nat. Prod. Res., 2008, 10(3-4), 259-265.

[46] Zhang, Z. Z.; Koike, K.; Jia, Z.; Nikaido, T.; Guo, D. A.; Zheng, J. H. New saponins from the seeds of Aesculus chinensis. Chem. Pharm. Bull., 1999, 47(11), 1515-1520.

[47] Yang, X. W.; Zhao, J.; Cui, Y. X.; Liu, X. H.; Ma, C. M.; Hattori, M.; Zhang, L. H. Anti-HIV-1 protease triterpenoid saponins from the seeds of Aesculus chinensis. J. Nat. Prod., 1999, 62(11), 15101513.

[48] Zhao, J.; Yang, X. W.; Hattori, M. Three new triterpene saponins from the seeds of Aesculus chinensis. Chem. Pharm. Bull., 2001, 49(5), 626-628.

[49] Zhao, J.; Yang, X. W. Four new triterpene saponins from the seeds of Aesculus chinensis. J. Asian Nat. Prod. Res., 2003, 5(3), 197203.

[50] Wei, F.; Ma, L. Y.; Jin, W. T.; Ma, S. C.; Han, G. Z.; Khan, I. A.; Lin, R. C. Antiinflammatory triterpenoid saponins from the seeds of Aesculus chinensis. Chem. Pharm. Bull., 2004, 52(10), 12461248 . 
[51] Yang, X. W.; Zhao, J.; Quyang, S. Studies on triterpenoid saponins from seeds of Aesculus wilsonii Rehd. Zhongcaoyao, 2002, 33(5), 389-391.

[52] Guo, J.; Yang, X. W. Studies on triterpenoid saponins of seeds of Aesculus chinensis Bunge var. chekiangensis. J. Chin. Pharm. Sci., 2004, 13(2), 87-91.

[53] Yang, X. W.; Guo, J. Isolation and identification of triterpenoid saponins from Aesculus chinensis Bunge var. chekiangensis. Zhongguo Xinyao Zazhi, 2007, 16(17), 1373-1376.

[54] Sakurai, T.; Nishimura, T.; Otake, N.; Yao, X. S.; Abe, K.; Zeida, M.; Nagasawa, H. Assamicin I and II, novel triterpenoid saponins with insulin-like activity from Aesculus assamica Griff. Bioorg. Med. Chem. Lett., 2002, 12(5), 807-810.

[55] Liu, H. W.; Zhang, X.; Gao, H.; Wang, N. L.; Jin, S. L.; Cai, B.; Yao, X. S.; Cai, G. P. Two new triterpenoid glycosides isolated from Aesculus assamica GRIFF. Chem. Pharm. Bull., 2005, 53(10), 1310-1313.

[56] Liu, H. W.; Yao, X. S.; Wang, N. L.; Cai, G. P. A new triterpenoid saponin isolated from the seeds of Aesculus assamica Griff. Chin. Chem. Lett., 2006, 17(2), 211-2114.

[57] Liu, H. W.; Wang, M. Y.; Song, X. Y.; Xia, Y.; Zhao, Y. S.; Song, X. H.; Jiang, M. M.; Zhang, X.; Gao, H.; Wang, N. L.; Yao, X. S. Three escin-like triterpene saponins: assamicins VI, VII and VIII. Helv. Chim. Acta, 2008, 91(9), 1704-1711.

[58] Singh, B.; Agrawal, P. K.; Thakur, R. S. Aesculuside-A, a new triterpene glycoside from Aesculus indica. Planta Med., 1986, 52(5), 409-410.

[59] Singh, B.; Agrawal, P. K.; Thakur, R. S. Aesculuside B, a new triterpene glycoside from Aesculus indica. J. Nat. Prod., 1987, 50(5), 781-783.

[60] Sati, O. P.; Rana, U. A new molluscicidal triterpenic glycoside from Aesculus indica. Inter J. Crude Drug Res., 1987, 25(3), 158160 .

[61] Zhang, Z. Z.; Li, S. Y. Cytotoxic triterpenoid saponins from the fruits of Aesculus pavia L. Phytochemistry, 2007, 68(15), 20752086.

[62] Ikram, M.; Khan, M. I.; Kawano, N. Chemical investigation of Aesculus indica. Planta Med., 1978, 34(3), 337-338.

[63] Ikram, M.; Khan, M.I. Chemical investigation of Aesculus indica. Part II. Fitoterapia, 1978, 49(6), 247-248.

[64] Hubner, G.; Wray, V.; Nahrstedt, A. Flavonol oligosaccharides from the seeds of Aesculus hippocastanum. Planta Med., 1999, 65, 636-642.

[65] Kapusta, I.; Szajwaj, B.; Stochmal, A.; Piacente, S.; Pizza, C.; Franceschi, F.; Franz, C.; Oleszek, W. Flavonoids in horse chestnut (Aesculus hippocastanum) seeds and powdered waste water byproducts. J. Agric. Food Chem., 2007, 55(21), 8485-8490.

[66] Wei, F.; Ma, S. C.; Ma, L. Y.; But, P. P.; Lin, R. C.; Khan, I. A. Antiviral flavonoids from the seeds of Aesculus chinensis. J. Nat. Prod., 2004, 67(4), 650-653.

[67] Curir, P.; Galeotti, F.; Dolci, M.; Barile, E.; Lanzotti, V. Pavietin, a coumarin from Aesculus pavia with antifungal activity. J. Nat. Prod., 2007, 10, 1668-1671.

[68] Kubo, I.; Ying, B. P. Phenolic constituents of California buckeye fruit. Phytochemistry, 1992, 31(11), 3793-3794.

[69] Morimoto, S.; Nonaka, G. I.; Nishioka, I. Tannins and related compounds. LIX. Aesculitanins, novel proanthocyanidins with doublybonded structures from A. hippocastanum L. Chem. Pharm. Bull., 1987, 35(12), 4717-4729.

[70] Bombardelli, E.; Morazzoni, P.; Griffini, A. Aesculus hippocastanum L. Fitoterapia, 1996, 67, 483-511.

[71] Simada, H. Constituents of the bark of Aesculus turbinata Blume (Hippocastanaceae). Yakugaku Zasshi, 1937, 57, 618-623.

[72] Kondo, T.; Ito, H.; Suda, M. Chemical studies on the bark constituents of Aesculus turbinata. Nippon Nogei Kagaku Kaishi, 1955, 29 , 950-952.

[73] Komissarenko, N. F.; Derkach, A. I.; Komissarenko, A. N.; Cheremnyova, G. V.; Spiridonov, V. N. Coumarins of Aesculus hippocastanum L. Rastitel'nye Resursy, 1994, 30(3), 53-59.

[74] Neamtu, G.; Bodea, C. Chemotaxonomic investigations on higher plants. VII. Carotenoid pigments in some species of Aesculus genus. Studii si Cercetari de Biochimie, 1974, 17(1), 41-46.

[75] Deli, J.; Matus, Z.; Toth, G. Comparative study on the carotenoids composition in the buds and flowers of different Aesculus species. Chromatographia, 2000, 51(Suppl), S179-S182.
[76] Srijayanta, S.; Raman, A.; Goodwin, B. L. A Comparative Study of the Constituents of Aesculus hippocastanum and Aesculus indica. J. Med. Food, 1999, 2(2), 45-50.

[77] Singh, B.; Agrawal, P. K.; Thakur, R. S. Long chain esters of Aesculus indica. J. Nat. Prod., 1989, 52(1), 180-183.

[78] Bhattacharya, M. K.; Ghosh, P. K.; Mukherjee, K. S. Chemical investigation of the leaves of Aesculus indica. J. Ind. Chem. Soc., 1981, 58(10), 1011-1012.

[79] Chen, X. S.; Chen, D. H.; Si, J. Y.; Tu, G. Z.; Ma, L. B. Studies on chemical constituents from the seeds of Aesculus wilsonii Rehd. Yaoxue Xuebao, 2000, 35(3), 198-200.

[80] Domagalski, W.; Schulze, A.; Bandurski, R. S. Isolation and characterization of esters of indole-3-acetic acid from the liquid endosperm of the horse chestnut (Aesculus species). Plant Physiol., 1987, 84, 1107-1113.

[81] Fowden, L.; Smith, A. Cyclopropane amino acid from Aesculus and Blighia. Phytochemistry, 1969, 8, 437-443.

[82] Fowden, L.; Smith, A. Newly characterized amino acids from Aesculus californica. Phytochemistry, 1968, 75(5), 809-819.

[83] Qin, W. J.; Yang, L.; Fan, Z. T.; Zhang, W. J.; Ma, L. B.; Tu, G. Z.; Xu, Y. N. Chemical constituents of Aesculus wilsonii. Zhongguo Yaoxue Zazhi, 1992, 27(10), 626-629.

[84] Guillaume, M.; Padioleau, V. Veinotonic effect, vascular protection, antiinflammatory and free radical scavenging properties of horse chestnut extract. Arzneimittelforschung, 1994, 44, 25-35.

[85] Sato, I.; Kofujita, H.; Suzuki, T.; Kobayashi, H.; Tsuda, S. Antiinflammatory effect of Japanese horse chestnut (Aesculus turbinata) seeds. J. Vet. Med. Sci., 2006, 68(5), 487-489.

[86] Muraki, K.; Imaizumi, Y.; Watanabe, M. Ca-dependent K channels in smooth muscle cells permeabilized by h-escin recorded using the cellattached patch-clamp technique. Pflugers Arch, 1992, 420, 461469.

[87] Pearson, P. J.; Vanhoutte, P. M. Vasodilator and vasoconstrictor substances produced by the endothelium. Rev. Physiol. Biochem. Pharmacol., 1993, 122, 1-67.

[88] Berti, F.; Omini, C.; Longiave, D. The mode of action of aescin and the release of prostaglandins. Prostaglandins, 1977, 14, 241-249.

[89] Panigati, D. Farmacologia dell'escina, saponina dell'Aesculus hippocastanum L. Parte II. Farmacologia dell'escina. Capitolo I. Boll. Chim. Farm., 1992, 131, 242-246.

[90] Matsuda, H.; Li. Y.; Yoshikawa, M. Possible involvement of 5-HT and 5-HT2 receptors in acceleration of gastrointestinal transit by escin Ib in mice. Life Sci., 2000, 66, 2233-2238.

[91] Facino, R. M.; Carini, M.; Stefani, R.; Aldini, G.; Saibene, L. Antielastase and anti-hyaluronidase activities of saponins and sapogenins from Hedera helix, Aesculus hippocastanum, and Ruscus aculeatus: factors contributing to their efficacy in the treatment of venous insufficiency. Arch. Pharm. (Weinheim),1990, 328, 20-24.

[92] Matsuda, H.; Li, Y.; Murakami, T.; Ninomiya, K.; Yamahara, J.; Yoshikawa, M. Effects of escins Ia, Ib, IIa, and IIb from horse chestnut, the seeds of Aesculus hippocastanum L., on acute inflammation in animals. Biol. Pharm. Bull., 1997, 20(10), 10921095.

[93] Patlolla, J. M.; Raju, J.; Swamy, M. V.; Rao, C. V. Beta-escin inhibits colonic aberrant crypt foci formation in rats and regulates the cell cycle growth by inducing p21(wafl/cip1) in colon cancer cells. Mol. Cancer Ther., 2006, 5(6), 1459-1466.

[94] Niu, Y. P.; Li, L. D.; Wu, L. M. Beta-aescin: A potent natural inhibitor of proliferation and inducer of apoptosis in human chronic myeloid leukemia K562 cells in vitro. Leuk Lymphoma, 2008, 49(7), 1384-1391.

[95] Niu, Y. P.; Wu, L. M.; Jiang, Y. L.; Wang, W. X.; Li, L. D. Betaescin, a natural triterpenoid saponin from Chinese horse chestnut seeds, depresses HL-60 human leukaemia cell proliferation and induces apoptosis. J. Pharm. Pharmacol., 2008, 60(9), 1213-1220.

[96] Zhou, X. Y.; Fu, F. H.; Li, Z.; Dong, Q. J.; He, J.; Wang, C. H Escin, a natural mixture of triterpene saponins, exhibits antitumor activity against hepatocellular carcinoma. Planta Med., 2009, 75(15), 1580-1585.

[97] Wang, P.; Ownby, S.; Zhang, Z. Z.; Yuan, W.; Li, S. Y. Cytotoxicity and inhibition of DNA topoispmerase I of polyhydroxylated triterpenoids and triterpenoid glycosides. Bioorg. Med. Chem. Lett., 2010, 20, 2790-2796.

[98] Yang, X. R.; Zhao, B. Z.; Cui, J. R. Anti-angiogenesis of sodium aescinate in vivo. Chin. J. New Drugs, 2006, 15(11), 868-870. 
[99] Zhao, B. Z.; Yang, X. R.; Guo, W.; Cui, J. R. Antiangiogenic effect and possible mechanism of sodium aescinate. Chin. J. New Drugs, 2007, 16(17), 1357-1360.

[100] Wang, X. H.; Xu, B.; Liu, J. T.; Cui, J. R. Effect of beta-escin sodium on endothelial cells proliferation, migration and apoptosis. Vascul. Pharmacol., 2008, 49(4-6), 158-165.

[101] Carrasco, O. F.; Vidrio, H. Endothelium protectant and contractile effects of the antivaricose principle escin in rat aorta. Vascul. Pharmacol., 2007, 47(1), 68-73.

[102] Montopoli, M.; Froldi, G.; Comelli, M. C.; Prosdocimi, M.; Caparrotta, L. Aescin protection of human vascular endothelial cells exposed to cobalt chloride mimicked hypoxia and inflammatory stimuli. Planta Med., 2007, 73(3), 285-288.

[103] Felixsson, E.; Persson, I. A.; Eriksson, A. C.; Persson, K. Horse chestnut extract contracts bovine vessels and affects human platelet aggregation through 5-HT(2A) receptors: an in vitro study. Phytother. Res., 2010, DOI: 10.1002/ptr.3103.
[104] Kimura, H.; Ogawa, S.; Katsube, T.; Jisaka, M.; Yokota, K. Antiobese effects of novel saponins from edible seeds of Japanese horse chestnut (Aesculus turbinata Blume) after treatment with wood ashes. J. Agric. Food Chem., 2008, 56(12), 4783-4788.

[105] Hu, J. N.; Zhu, X. M.; Han, L. K.; Saito, M.; Sun, Y. S.; Yoshikawa, M.; Kimura, Y.; Zheng, Y. N. Anti-obesity effects of escins extracted from the seeds of Aesculus turbinata Blume (Hippocastanaceae). Chem. Pharm. Bull., 2008, 56(1), 12-16.

[106] Sato, I.; Suzuki, T.; Kobayashi, H.; Tsuda, S. Antioxidative and antigenotoxic effects of Japanese horse chestnut (Aesculus turbinata) seeds. J. Vet. Med. Sci., 2005, 67(7), 731-734.

[107] Küçükkurt, I.; Ince, S.; Keleş, H.; Akkol, E. K.; Avci, G.; Yeşilada, E.; Bacak, E. Beneficial effects of Aesculus hippocastanum L. seed extract on the body's own antioxidant defense system on subacute administration. J. Ethnopharmacol., 2010, 129(1), 18-22.

[108] Chan, P. K. Acylation with diangeloyl groups at C21-22 position in triterpenoid saponins is essential for cytotoxicity towards tumor cells. Biochem. Pharmacol., 2007, 73, 341-350.

This is an open access article licensed under the terms of the Creative Commons Attribution Non-Commercial License (http://creativecommons.org/licenses/ by-nc/3.0/) which permits unrestricted, non-commercial use, distribution and reproduction in any medium, provided the work is properly cited. 